\title{
NAUFRÁGIO E GALANTEIO: viagem, cultura e cidades em Mário de Andrade e Gilberto Freyre*
}

\author{
José Tavares Correia de Lira
}

O estímulo epidérmico, o exótico, o pitoresco prendem só o estrangeiro. Bem outra e mais profunda é a inspiração que leva a representar uma cidade pela perspectiva de um nativo: é a perspectiva de quem se desloca no tempo em vez de se deslocar no espaço.

Walter Benjamin

* Um primeiro ensaio de abordagem do material de viagem de Mário de Andrade do ponto de vista da história urbana, foi realizado com o arquiteto George Dantas (cf. Dantas e Lira, 2001). Este artigo constitui uma versão abreviada do trabalho apresentado no GT Pensamento Social no Brasil, do XXVII Encontro Anual da Anpocs, Caxambu out. 2003, sob coordenação de Fernanda Arêas Peixoto e Marcos Chor Maio. Desde então, Fernanda Peixoto tornou-se para mim uma interlocutora decisiva nesta tênue fronteira entre arquitetura, antropologia e história intelectual.

Artigo recebido em maio/2004

Aprovado em novembro/2004
Em fevereiro de 1929, à pedido do jornal $A$ Província, Mário de Andrade publicou no Recife um depoimento sobre a viagem que encerrava pelo Nordeste. O jornal the pedira as primeiras impressões de fim de percurso. "Isso por enquanto é difícil", respondeu Mário. "Impressões muitas, às vezes desencontradas. Estou assim como quando a jangada vira e a gente é sacudido ao mar: primeiro tenho que me salvar" (Andrade, 1929).

A imagem eleita para descrever o que vira pelo Nordeste certamente repercute o estágio de campo desta viagem etnográfica feita com total disponibilidade e pouco método, de colheita paciente e sem preconceitos, bem diferente da preguiça criativa na viagem pela Amazônia em 1927. Trabalho infatigável apesar de pouco esquematizado, o tour nordestino pedia cautela e muito estudo por fazer para julgar. Tanto que naquele mesmo fim de tarde deste seu último sábado pernambucano, às vésperas de embarcar de volta 
para São Paulo, o turista apenas iniciado em antropologia (Lopez, 1972, pp. 83-85) partiria para um fim-de-semana no engenho da família do pintor Cícero Dias, na Zona da Mata Sul, à procura das danças e das cantorias que o carnaval, o pileque e a ressaca haviam amortecido na capital.

A imagem é também eloqüente pela confissão de estupor do viajante. Um misto de excitação e encantamento que retinha o comentário e desnorteava o forasteiro ao se descobrir atolado na terra estranha. "Descobri que sou nordestino" (Branco, 1971, p. 76); um pólo de sonho da existência contra "a mecânica da vida pra S. Paulo" (Mello, 1991, p. 92). A metáfora do naufrágio em meio ao "dilúvio" de documentos e observações críticas que juntara remete a uma experiência fundamental de deslocamento. A viagem não apenas aprofundava a cisão primitivista na posição de vanguarda (G. de M. e Souza, 1980), mas afirmava uma descontinuidade cultural: a relatividade dos códigos impunha-se à experiência constitutiva da divisão entre o colonizador e o colonizado, a civilização moderna e a tradição popular, o ponto de origem e o itinerário (Lévi-Strauss, 1987; Ricoeur, 1955); algo mais do que mera mudança de lugar em um mesmo mundo, mas como "uma empreitada no tempo" (Cardoso, 1988), transformação e diferenciação de seu próprio mundo na impossibilidade da experiência e do conhecimento do outro (Peixoto, 1992).

Em agosto 1927, Mário retornava da Amazônia. Em um passeio de lancha pelo Capibaribe, o recifense Gilberto Freyre apresentava um outro ângulo da cidade ao urbanista Donat Alfred Agache (Bruant, 1996). Este novo engenheiro francês, recém-chegado ao Rio de Janeiro para estudar um plano de extensão da capital federal, era cogitado para projetar um plano de remodelação, embelezamento e expansão também ali. ${ }^{1}$ Agache viera ao Recife a convite do governador Estácio Coimbra, de quem Gilberto Freyre era chefe de gabinete. Ali proferiria algumas conferências sobre o conceito de urbanismo, na linha organicista registrada em seu plano para o Rio de Janeiro (Agache, 1930), ${ }^{2}$ como de praxe reforçando as virtudes de um contato direto com o corpo da cidade, à procura de suas particularidades e características locais, fun- damento de toda intervenção urbanística. Como nos informa o cicerone local, não houve recanto da cidade que Agache não insistisse em conhecer: becos, vielas, "os chamados quadros. Também as mucambarias", e a velha e já inusitada perspectiva da cidade a partir do rio. Foi da embarcação que o sociólogo anotou esta impressão: "Fixei o urbanista: a cidade vista do meio do rio principiava a empolgá-lo... O urbanista tinha o ar, que não disfarça, de um Don Juan deveras interessado por um caso novo. Don Juan de cidades". 3

Do meio do rio, Agache parecia-lhe descobrir os véus da moura: cidade "a mais árabe das que os portugueses criaram no Brasil", mais lusitana que haussmaniana, mais feminina que masculina, oriental e aquática. ${ }^{4}$ Pouco fotogênica, deixava de fora apenas metade do rosto, cheia de encanto e sedução de beleza recatada de viúva de Conde. Bem diferente do Rio de Janeiro ou da Bahia - o paralelo antológico -, capitais exibidas onde tudo saía fácil e bonito como em cartão postal. ${ }^{5}$ Mas eis que perante o especialista em ciência urbana, obstinado encantador de tudo quanto era burgo velho e novo, a cidade seqüestrava os direitos do sedutor:

[...] começa na Rua da Aurora sendo fotogênico para quem o vê do meio do rio; mas é descer a gente o rio ou ganhar as ruas e os pátios de dentro de Santo Antonio e de São José e vê que a capital de Pernambuco guarda valores característicos a cujo encanto nenhuma lente de câmara de cinema poderia fazer justiça. [...] Mestre Agache era agora quase um lírico a falar da necessidade de reconciliar a cidade com as suas águas tão lindas por onde a lancha subia. ${ }^{6}$

Significativo para a história do urbanismo no Brasil, o episódio sugere um triângulo interessante entre a cidade, o estrangeiro e o nativo. Pois se o filho da terra repetia o Don Juan, conduzindoo pela fisionomia local pouco visível, na corte ao visitante também lhe facultava o encantamento. O guia sentimental abolia a norma turística e introduzia as balizas da evocação, da intuição e da imaginação no acesso a um certo "caráter" sedutor da cidade; não previsto, incerto, que atualizava a alegoria da "viagem de um mundo a outro". 
Mais do que a transposição de uma distância, tratava-se de suscitar no observador - estrangeiro ou nativo - um novo modo de ver, uma mudança de perspectiva, pelo comércio entre o próprio e o ignorado, o seu mundo e o outro mundo.

As anedotas sugerem um encontro entre o turista aprendiz e o aprendiz de cicerone. Ainda que improvável, afinal estes verdadeiros "irmãos inimigos" (G. de M. e Souza, 2000, p. 74), chefes de fila do modernismo paulista e do regionalismo pernambucano, fixaram para a posteridade os desencontros e extremos entre Sul e Norte (Chacon, 1993), os perfis emblemáticos do homem urbano que surgia e do remanescente disponível à velha ordem (G. de M. e Souza, 1980, pp. 109-110). Na verdade, na tarde do dia 12 de dezembro de 1928 , no início de sua viagem pelo Nordeste, Mário já havia se encontrado com Gilberto em um outro passeio de lancha pelo Capibaribe na companhia de Manuel Bandeira, amigo pessoal de ambos. Colaborador regular do jornal A Província, ${ }^{8} \mathrm{O}$ autor de "Evocação do Recife" chegara do Rio de Janeiro fazia um mês. ${ }^{9}$ Em seu diário de bordo, Mário anotou: "Tarde M. Bandeira me busca no hotel e me leva a Gilberto Freyre, que nos oferece um passeio de lancha pelo Capibaribe, maravilhoso, com vista da cidade". ${ }^{10}$

É verdade que o encontro não deve ter sido lá muito cortês. Pelo menos é o que se entrevê de seus escritos privados, acessíveis em livro. O desencontro é que ficou muito conhecido. A economia de Mário nas referências ao condutor ao longo das cartas e notas de viagem é eloqüente. Afinal Gilberto compartilhava com ele de inúmeras amizades e naqueles anos era talvez a pessoa mais instruída para conduzi-lo pelas coisas de etnografia e folclore em Pernambuco. Se na correspondência com Bandeira é patente a indiferença ante o terceiro, em carta a Cascudo de finais de 1926, o ano do Congresso de Regionalismo no Recife, Mário confessara indisposição para com a mentalidade recifense: "me parece gente sem sensibilidade nova, sem esta agilidade intelectual desabusada que é tão característica de nosso tempo e que você tem". ${ }^{11}$ Inclusive Joaquim Inojosa, junto com quem o poeta Ascenso Ferreira o recebera de passagem para a Amazônia em 1927. Opo- sitor modernista de Gilberto (Azevedo, 1984; Rezende, 1997), ${ }^{12}$ é até compreensível certa cerimônia deste para com Mário, mas o que ele anotou em seu diário de mocidade naquele ano sugere maior constrangimento:

Má impressão pessoal de M. de A. Sei que sua obra é das mais importantes que um intelectual já realizou no Brasil [...]. E sua pessoa é o que acentua: o lado artificioso de sua obra de renovador das artes e das letras no Brasil. Seu modo de falar, de tão artificioso, chega a parecer - sem ser delicado em excesso. Alguns dos seus gestos também me parecem precários (Freyre, 1975, p. 207).

Dois anos depois, quando da segunda viagem ao Norte, Gilberto emendaria taxativo: "Mário de Andrade não me interessa" (Idem, p. 233). O que estava em jogo desta vez era a colaboração dos modernos talentos do Rio de Janeiro e de São Paulo ao jornal A Província, o mesmo que sob sua direção convidara Mário para escrever sobre a região ao final de sua viagem. O fato é que na abertura do seu elogioso artigo sobre o Nordeste, Mário não escondeu o desconforto de paulista em tour:

Gozei muito. Gente boa me tratando com carinho de mâno, às vezes um bocado de despeito pelas grandezas de São Paulo, glozadas, aumentadas e servindo de pretexto pra muita queixa... Não tenho a culpa das grandezas de São Paulo e não as considero tão guassús. Algumas existem de fato, outras são de pura fantasia (Andrade, 1929).

\section{Navegante de primeira viagem}

Mário de Andrade foi talvez o primeiro, senão o único dos grandes intelectuais brasileiros a não realizar nem a projetar o grand tour tradicional pela Europa (Ciacchi, 1995, p. 9; Salgueiro, 2002). Experiência tardia, a viagem surgiu-lhe inicialmente marcada por circunstâncias pessoais, freqüentemente funcionando como instância de solidarização do grupo modernista a que pertencia. ${ }^{13}$ Ao congregado mariano, as viagens exortavam o estudo dos festejos religiosos, suas procissões, cortejos, autos, danças, mascaradas e luminárias (Andrade, 1920b, pp. 5-12); ao professor do Conservatório 
Dramático e Musical, a ampliação das fontes populares de parlendas e cantigas (Lopez, 1983; Souza e Schmidt, 1997). Viagens de arredores, desde cedo Mário as veria como uma posição: "Não censuro o brasileiro que quer ver Paris, desejaria apenas que elle visse a Bahia, o Rio das vielas estranguladas que ladeiam a Avenida Central e principalmente abrisse o Sésamo acolhedor e encantado de Minas" (Andrade, 1920c, p. 108). Mesmo que as "lindas coisas" do país ainda não funcionassem como alternativa às convenções acadêmicas (Moraes, 1999, pp. 79-80), e ainda não operassem claramente comprometidas no sentido de um reaproveitamento culto da arte popular (Fernandes, 1946), do nivelamento e desnivelamento estético (G. de M. e Souza, 1979, pp. 20-21).

Como sabemos, a histórica "viagem da descoberta do Brasil" através das cidades históricas de Minas em 1924 representou para o modernismo brasileiro uma guinada dialética fundamental - porque travejada pelo influxo das vanguardas contemporâneas - no enfoque do nacionalismo e da tradição no Brasil (G. de M. e Souza, 1980, pp. 256-259; Lopez, 1983, pp. 15-16). Transposto para a arte colonial barroca, com ela, definitivamente, o culto do primitivo tornou-se o lugar "do novo e do mistério representado pelos moços" (E. M. de Souza, 1999, p. 211); um encontro entre o primitivismo das vanguardas e a sensibilidade brasileira, "a viagem consolida no poeta a comunhão com a arte do povo" (Lopez, 1993, p. 109). ${ }^{14} \mathrm{Em}$ sua poesia doravante percebe-se o aflorar de uma disposição para sair de casa: "Como será a escureza/ Desse mato-virgem do Acre? (Andrade, 1976, pp. 182-184).

Foi dessa curiosidade, que, em 1927, surgiu para Mário de Andrade a viagem à Amazônia. Sabe-se que a idéia original era ir ao Nordeste; que partira da milionária Olívia Guedes Penteado a sugestão do Amazonas, imediatamente abraçada pelo escritor no afã de reescrever o Macunaíma, iniciado em fins de 1926; e que deveria ter sido realizada por um grupo semelhante ao do passeio por Minas Gerais: "resolvi ceder mandando à merda esta vida de merda". ${ }^{15}$ Ao final, a comitiva seria reduzida à mecenas do modernismo, sua sobrinha Margarida e a filha de Tarsila do Amaral, Dulce. Também em detrimento de Mário, a expedição seria marcada por um forte acento protocolar, certamente enobrecida pela ascendência inevitável desta ilustre dama da oligarquia cafeeira desembarcando nesta parte do país de oligarquia já saudosa da belle époque do látex (Sarges, 1990; Masacarenhas, 1999).

$\mathrm{Na}$ interpretação da obra de Mário, a viagem ocupa um lugar importante, seja como momento de complementação das fontes folclóricas, míticas e lingüísticas do Macunaíma em redação (Lopez, 1972, p. 79), ${ }^{16}$ seja como principal ingrediente de definição antropológica do herói sem caráter (Branco, 1971, pp. 59 e 67), seja ainda para a compreensão de sua biografia - a viagem parodiando um roteiro tornado folclórico na família (G. de M. e Souza, 1978), cristalizando um vínculo emocional com a cultura popular (Duarte, 1972 , p. 28), e nele antecipando a figura do intelectual engajado na política cultural e na etnografia na década seguinte (Lafetá, 2000, pp. 151-184; Sandroni, 1988; Raffaini, 2001). Ainda está por ser melhor avaliada, porém, a experiência da viagem como "descartografia" e utopia geográfica, como reencontro da experiência civilizatória brasileira no deslocamento, no desvio, na descoberta de seus vícios e nas possibilidades latentes.

\section{As cidades amazônicas: artifício, mito e evasão}

É certo que a peregrinação à Amazônia não se deixou caracterizar como uma empreitada de proselitismo modernista. Em sua motivação francamente amorosa, no registro diário da viagem, aspirando inclusive à condição de livro independente, ${ }^{17}$ a identidade de escritor seria vivenciada como incômodo à condição do viajante. $\mathrm{E}$ isto também quanto à viagem ao Nordeste, onde o contato de Mário com os jovens, bem maior que no Norte, por certo aprofundou a tendência à normalização do espírito de vanguarda em cultura brasileira. Em ambos os casos a partida foi vivida como desenraizamento, malgré lui, foi "no exílio" 
que aprendeu o turismo (Meyer, 1993, pp. 34ss.), aprendizado não sem atropelos e vacilações.

Na partida de São Paulo, sua bagagem já foi um problema: o que levar? uma bengala? um canhão? um revólver? (O turista aprendiz, 7/5/1927). Afinal, ia de encontro a "tribos selvagens, jacarés e formigões". O embarque no Rio de Janeiro foi cercado de inquietações (Idem, 11/5/1927), denunciando um viajante, até então, talvez, mais resolvido a escrever a epopéia modernista do que a navegar: "antiviajante que sou, viajando sempre machucado, alarmado, incompleto, sempre se inventando malquisto do ambiente estranho que percorre", confessaria anos depois. No destino, constatou: "se vê que ainda não sei viajar" (Idem, 21/5/1927). E não porque muito preso à terra natal: "É certo que não sou de psicologia tipo turista, isso já não tenho mais dúvida, mas também só umas três vezes terei sentido alguma saudade de São Paulo e dos meus. [...] Será uma falha minha?" (Idem, 21/7/1927), escreveu ao retornar.

Nessa viagem entediante pelo atlântico até Belém, dias "feitos de nada" que se alongavam pelos rios, o desconforto da civilização se impôs:

[...] estou um bocado aturdido, maravilhado [...]. Há uma espécie de sensação ficada da insuficiência, de sarapintação, que me estraga todo o europeu cinzento e bem-arranjadinho que ainda tenho dentro de mim. Por enquanto o que mais me parece é que tanto a natureza como a vida destes lugares foram feitos muito às pressas, com excesso de castro-alves. E esta pré-noção invencível de que o Brasil em vez de se utilizar da África e da Índia que teve em si, desperdiçou-as, enfeitando com elas apenas a sua fisionomia, suas epidermes, sambas, maracatus, trajes, cores, vocabulário, quitutes... E deixou-se ficar, por dentro, justamente naquilo que, pelo clima, pela raça, alimentação, tudo, não poderá nunca ser, mas apenas macaquear, a Europa. Nos orgulhamos de ser o único grande (grande?) país civilizado tropical... Isso é o nosso defeito, a nossa impotência. Devíamos pensar, sentir como indiano, chins, gente de Benin, de Java... Talvez então pudéssemos criar cultura e civilização próprias (Idem, 18/5/1927).

O senso de responsabilidade social era aguçado em busca de identidade. Mas a paisagem do
Norte, já de início, decepcionava - menos brasileira do que esperava, mais artificial, burguesa e belle époque, pior, feita às pressas. Cioso por libertarse da bagagem européia, flagra-se um Mário impaciente com seus pressupostos: com o aspecto de civilização de epiderme, de macaqueação tropical, em nome de camadas desperdiçadas da formação brasileira; com suas noções prévias sobre o primitivo, para sua infelicidade, surpreendido in loco, ele mesmo, como um construto intelectual. Chegando a Belém, confessa modestamente a um repórter: "É um passeio sem heroísmo o que fazemos". ${ }^{18}$ Belém surge neste ponto da viagem, antes de tudo, sensivelmente: a chuva, os calores, o cheiro da carne-seca, as velas coloridas das embarcações, verdes de horizonte, o sabor do açaí. Logo, porém, irá se revelar o acento protocolar que acompanharia a comitiva: o mundo cerimonial "donoliviando-lhes" com flores e retretas em cada embarque e desembarque, recepções e visitas oficiais: "Falei que tudo era muito lindo, [...] que nos parecia que tinham se eliminado os limites estaduais!" (Idem, 20/5/1927). Diplomacia à parte, o esforço de enraizamento é claro: no embaraço de saudações a antigeografia e o anti-regionalismo funcionavam. Essa circunstância é fundamental na viagem à Amazônia: prefeitos, governadores, religiosos, chefes de polícia, professoras públicas revezando-se "de bedéquer" (Idem, 16/6/1927). Tanto pior para Mário de Andrade, naturalmente convertido em porta-voz e acompanhante da Rainha do Café na terra esborrachada economicamente. Em Iquitos, parece que ele já não agüentava mais as "caceteações [...]. Como os reis em Londres ou na Itália, viva o protocolo!" (Idem, 22/6/1927); na volta da Bolívia, é a própria Dona Olívia quem suspira: "Ah. Mário... essa história de todos os prefeitos se verem na obrigação de acompanhar a gente, levar na prefeitura, no grupo..." (Idem, 17/7/1927). Compreende-se o sentido de refúgio na vida de bordo, escape à convenção e à compostura; a própria preguiça ganhava prestígio no momento da criação ante as atribulações da vida civilizada (Lopez, 1972, pp. 110-118). A entrada na selva pela foz, entre revoadas e jantares apetitosos, descrevem também uma apropriação estética do enfado. 
É também nesta circunstância que teremos que procurar a composição de seus itinerários urbanos, em grande parte convencionais, haja vista os cicerones. Notemos nos desvios como modo particular de mapeamento e desreferencialização da cidade. A estratégia de Mário passará pela familiaridade imediata: "já me acamaradei com tudo" (O turista aprendiz, 20/5/1927); "Belém foi feita pra mim" (Idem, 23/5/1927). O entusiasmo com o distante que se reflete em estranhos mitos de origem: "mandaram vir u'a imigração de malaios e no vão das mangueiras nasceu Belém do Pará." (Idem, 20/5/1927). Polinésia, Cairo, lugares remotos que apareciam em sensações, assim como adiante Santarém: lá "os venezianos falam muito bem a nossa língua e são todos duma cor tapuia escura. Fomos recebidos com muita cordialidade pelo doge que nos mostrou a cidade" (Idem, 31/5/1927). Fábulas de cidade e imagens arquetípicas da cidade oriental, que descontraíam e informalizavam o outro. Mas na cidade histórica, além do patrimônio colonial, aliás ameaçado, havia também o Goeldi e o Vêr-o-peso como referências. É verdade que não escondiam a Paris tropical das ciências naturais e etnográficas e da higiene a Antônio Lemos (Sarges, 1999, pp. 49-74). Mas a flora, a fauna e a cerâmica bem mostradas, a biblioteca admirável e, no mercado, o melhor de Belém (O turista aprendiz, 20/5/1927), seus aromas, cores e sabores, traziam de volta a cidade "mais gostosa deste mundo!", entre refrescos róseos, roxos e verdes, gostosíssimos: "Vale mais que Melbourne ou Nova York" (Idem, 21/5/1927).

Contra a plena identificação com a cidade, além do protocolo, gritava a mania a arborizá-la com plantas estrangeiras, insuportavelmente monótonas, destoantes do clima. "Imagine só uma alameda arborizada com tufos de açaizeiros? [...] Aproveitando seu espírito de imitação, Belém será a mais linda cidade equatorial". ${ }^{19}$ Era preciso recuperar o parentesco com a singularidade regional.

Em 5 de junho, o cruzeiro chega a Manaus e, de novo, à chatice de cortejo na recepção. Naquela tarde, guiado pelo comandante da polícia, Mário vai ao bairro da Cachoeirinha "visitar o arraial da igreja do Pobre Diabo, onde tinha festa" (Idem, 5/7/1927). Era nesses bairros populares, que ele escapava dos hospitais e orfanatos, da Associação Comercial, da fábrica de borracha ou de cerveja. Fora isso, muito pouco. A despeito da camaradagem especial ali com os moços, da hospitalidade baré, de uma maneira geral a cidade não lhe agradou: além de tudo o calor sufocante tornou Mário "alérgico à capital do Amazonas". E de fato escreveu algo assim,

[...] toda essa falsificação de grandeza, todo esse mau-gosto exasperado e... morto de grandezas passadas, toda a falta de caráter individual (Santarém tem mais caráter até Fonte Boa), os ficus, tudo isso e em ponto-pequeno, me desagradou, me irritou. E me entristeceu principalmente porquê Manaus sendo um milagre jogado no sertão, afinal das contas é um milagre feio, um milagre sem caracter e o que é mais horroroso ainda, um milagre já hoje sem razão. ${ }^{20}$

$\mathrm{Na}$ confissão ao amigo poeta, prefeito de Humaitá no Amazonas, seu fornecedor de folclore musical amazônico, a cidade surgia-lhe como quintessência de um processo caricatural de urbanização; grandiloqüência civilizatória que mal disfarçava a destruição da natureza ${ }^{21}$ e a maleita. De promessa de aproximação aos sertões amazonenses, a cidade tornara-se prova mais visível da falsidade, mau gosto e indiferença em nome de pretensa integração nacional. O próprio teatro era uma "mistura agressiva de riqueza falsa e desleixos de acabamento" (Idem, 20/7/1927), faltava caráter na arborização exótica. Ao ser questionado pela imprensa local, o escritor não hesitaria em denunciar as ilusões do fausto, os adornos efêmeros de um progresso inconstante, já bem distante dos anos de esbanjamento e cujas duras conseqüências já podiam ser sentidas na "miséria e servidão de milhares de caboclos": duro aprendizado que se impunha aos contemporâneos. De "virgem de luxo" a cidade passara a "mulher fecunda": os governos deveriam ser criativos para gerar "nova florada de empreendimentos de alcance elevado". ${ }^{22}$

O mesmo tipo de censura que viria a propósito quanto ao Álbum de Manaus, a ele presenteado pelo prefeito Araújo Lima, editado no afã do turismo para esta parte do país inviabilizada pela 
bancarrota precoce da goma elástica. Só uma objeção, onde "a cidade salubre"? onde o clima muito tolerável? Por que estas "ruas largas e calçadas, praças ajardinadas e logradouros públicos encantadores"?23 O problema era que a prefeitura só tinha olhos para o lado pitoresco da civilização: a promoção turística não seduzia o turista aprendiz, e se o tour oficial era difícil de evitar, não era o caso de recomendá-lo. Por sorte, a partir de Manaus a viagem mais e mais enveredava pelas selvas; os roteiros oficiais, podendo ser evitados em favor de passeios pelos arrabaldes populares e à floresta: à Cachoeirinha, ao Careiro, ao lago do "Amaniúm", à cachoeira de Tarumã, à Vitória-régia, às embarcações, às tribos e aldeias, aos ritos indígenas, às cantigas e festas populares, emancipando-se de vez do itinerário diplomático e de suas companheiras (Idem, 8/6/1927 e 17/7/1927), podendo perder-se pelas ilhas e matas, pela poesia.

Depois de Manaus, só cidadezinhas e lugarejos - Óbidos, Fonte Boa, Remate de Males, Iquitos, Humaitá. Uma delas apareceria em sonho, chamava-se Itacoatiara, não existia no mapa, mas encenava parodicamente a cidade na floresta:

É a mais linda cidade do mundo, só vendo. Tem setecentos palácios triangulares feitos com um granito muito macio e felpudo, com um porta só de mármore vermelho. As ruas são todas líquidas, e o modo de condução habitual é o peixe boi e, pras mulheres, o boto. Enxerguei logo um bando de moças lindíssimas, de encarnado, montadas em boto que as conduziam rapidamente para os palácios, onde elas me convidavam pra entrar em salas frias, com redes de ouro e prata pra descansar ondulando. Era uma rede só e nós dois caíamos nela com facilidade. Amávamos. Depois íamos visitar os monumentos públicos, onde tornávamos a amar porque os todos burocratas estavam ocupados, nem olhavam. As ruas não se chamavam com nome de ninguém, não. Tinha a rua do Meu Bem, a rua das Malvadas, a rua Rainha do Café, a rua das Meninas, a rua do Perfil Duro, a rua do Carnaval, a rua Contra o Apostolado da Oração (Idem, 3/6/1927).

A cena fantástica, ao lado de sua componente utópica, revela a oscilação satírica entre o modelo oriental da cidade invisível, com seus palá- cios revestidos de granito e mármore, e a diferença local, a rede, as ruas cobertas de água de nomes bem nortistas em alusão ao amor, ao pecado e às companheiras de viagem. A paródia onírica ressoava e amplificava o disparate da cidade européia com a extravagante arquitetura de estilo em plena floresta. O macio, o felpudo, o vermelho, o líquido, o peixe-boi, o boto e as mulheres, suas parceiras, com a "elegância discreta embora desenvolta com que elas sabem ficar nuas, que diferença das mulheres civilizadas" (Idem, 4/6/1927), faziam da cidade o espaço do erotismo. Além delas, apenas o burocrata indiferente e o estrangeiro, que, enamorado pelas nativas, se deixava levar a toda parte em prol do amor. Este urbanismo surrealista de Mário de Andrade levava ao extremo as impressões paradisíacas de suas Venezas e Cairos amazônicos, antepunha à imagem séria e ascética do roteiro turístico, uma cultura popular, carnal, que promovia a liberação do riso, a vitória do sexo sobre a oficialidade - Uraricoera vivida sem recalques. ${ }^{24}$

Experiências de cidades que ao serem "desgeograficadas" macunaimicamente criam novas geografias, mapas legendários, livres de contingências regionais, embrulhados de propósito, mas também livres das convenções e dos modelos de exportação, ${ }^{25}$ capazes de criar na pátria expatriada um "itinerário fantástico, uma espécie de utopia geográfica, que corrige o grande isolamento em que os brasileiros vivem, substituindo-o pelo elo fraterno da vizinhança" (G. de M. e Souza, 1979, pp. 38-39). Daí talvez a eleição das selvas e confins, o recurso ao mito da Cidade Afundada ( $O$ turista aprendiz, 4/7/1927).

\section{Cantos e recantos das cidades nordestinas}

A viagem ao Nordeste não tarda. A idéia vinha sendo acalentada desde 1924, na correspondência com Luís da Câmara Cascudo. ${ }^{26}$ "Não tendo coragem de mandar trabalho e todo o resto à merda e ir viajando por onde me chama esta sodade misteriosa das coisas que inda não vi". ${ }^{27}$ Algo até já planejado e quase orçado em 1926. ${ }^{28}$ Em 1928, 
a viagem seria tão longa quanto em 1927 (mais de cem dias), sob um aspecto, mais livre; sob outro, mais obrigada. Mário desta vez viaja só, portanto, isento dos compromissos de cavalheiro e protocolo, porém a trabalho: chama a expedição de "viagem etnográfica" e em parte ela será custeada pela função de cronista do Diário Nacional, em que era responsável pela coluna diária, que chamará durante a ausência de São Paulo de "O turista aprendiz". Diferente no objetivo e na prosa, a viagem sofre outra mutação fundamental: as mediações com o destino não se dão agora pelas autoridades locais, mas pelos amigos, modernistas e simpatizantes, seus anfitriões, cicerones ou condutores pelas coisas populares. A mudança de estação também é decisiva. Se o inverno era no Norte a melhor época para a colheita folclórica, Mário desta vez viaja no verão para aproveitar em campo as festas do ciclo natalino ao carnaval, de encenação das danças dramáticas. ${ }^{29}$

A situação se antecipara nos dias de camaradagem intelectual intensa no Rio de Janeiro (Idem, 28/11/1928 a 3/12/1928); em Maceió, escreveu, "fui levado no embalanço dos amigos" (Idem, 9/12/1928); no Recife, "com Ascenso me esperando às 7hs" (Idem, 11/12/1928); em Natal, "me esperavam Cascudinho, Antônio Bento" (Idem, 14/12/1928); no caminho de João Pessoa, me esperavam "José Américo de Almeida, Ademar Vidal e Silvino Olavo" (Idem, 27/1/1929); na despedida do Recife, "apareceu Dr. Gouvea de Barros, Avelino Cardoso, Ascenso, Stella, Jaime Gris, Cícero Dias, Willy Lewyn, Rabelinho [Sylvio Rabelo], José Pinto, Ernani Braga, Murilo Lagreca" (Idem, 20/2/1929). Outra mudança: o viajante é recebido como escritor paulista (e não acompanhante da dama), autor de Macunaíma, introduzido à realidade nordestina pela geração mais jovem da intelectualidade local. Entre os guias: artistas, jornalistas e escritores da nova geração. Mário está quase sempre acompanhado e muito próximo dos da terra: a casa de Cascudo, sua morada e base de trabalho em Natal; a casa de Ademar Vidal, apoio na Paraíba; os engenhos das famílias de Antônio Bento e Cícero Dias, pontos avançados de pesquisa no interior. O amado Inojosa, o gozado Ascenso, Jorge Fernandes, Barôncio Guerra, Cristóvam Dantas,
Cascudo, companheiros contumazes de banho de mar, de passeio, de banzo, de pesquisa. Em toda parte, "gente suavíssima que me quer bem, que se interessa pelos meus trabalhos, que me proporciona ocasiões, de mais dizer que o Brasil é uma gostosura de se viver" (Idem, 2/2/1929). No embalo da vida vivida na existência do amigo, o turista abre caminho pelo outro.

O encontro afetuoso compensava a sensação desagradável de ingressar em "vida viajeira". As partidas de São Paulo e do Rio de Janeiro de novo foram penosas: "está provado que não fui feito pra viajar" (Idem, 27/11/1928); uma sensação de estar em dois, de viagem interior, "o novo, ajuntado agora a mim, é um desconhecido até desagradável capaz de enfrentar a onda enorme do oceano. Vai viajar, vai pro Nordeste". Mas bastava botar o boné na cabeça que "era eu viajando" (Idem, 3/12/1928). A viagem de navio até a Bahia foi marcada por um misto de enlevo e semi-enjôo (Idem, 6/12/1928). Pois se o Rio parecia quase extensão da vida paulistana, cercado dos velhos companheiros de combate, Sérgio, Prudente, Graça, Almeida e outros, Salvador lhe deu o primeiro choque de deslocamento com a sonora visão da cidade: o amontoamento das casas, o estardalhaço das janelas e telhados, as ruas que trepavam e trombavam, os vários planos de movimento, a sensação física de simultaneidade - "o barulho nem é tamanho assim porém dá impressão de enorme" (Idem, 7/12/1928). Sensualidade de passagem na rota procurada da embriaguês. Também de passagem, Maceió dá os primeiros indícios do povo: acompanhado dos amigos escritores, encontra-o na feira de domingo de Fernão Velho construindo a barcaça para a Nau Catarineta,

[...] e a caboclada brasileira há-de repisar mais uma feita sem consciência de heranças, brasileira como alagoana, aqueles portugas do fastígio que pra voltar das aventuras passava ano e mais ano buscando terra de Espanha, areias de Portugal... Tudo isso enche meu peito que nem posso respirar (Idem, 9/12/1928).

É este povo que será figura onipresente na viagem. Até mesmo no espaço coloquial da crônica que descreve o itinerário - publicadas cerca 
de quinze ou vinte dias após a redação - Mário encontrará tom adequado à confissão de seu assunto fundamental. Das setenta crônicas publicadas pelo jornal desde a partida de São Paulo, mais de vinte tratam diretamente de cultura popular. ${ }^{30}$ Pontuam o itinerário do começo ao fim e freqüentemente perpassam os outros temas da escrita, como as condições de vida dos trabalhadores rurais, a economia local, as paisagens e misérias dos sertões, a migração, a cidade, os bairros populares, a arte religiosa, os casos e anedotas, o cajú, os anfitriões, em tudo o escritor é permeado pela personagem popular, sua tradição oral, o ethos do cantador. Também no pequeno diário manuscrito, as "Notas de viagem ao nordeste" que encerram de maneira telegráfica o registro mais íntimo e as anotações avulsas da jornada (O turista aprendiz, p. 37), os levantamentos quase diários: "Não saio de casa. Colho melodias" (17/12); "Temas de chegança" (20/12); "De manhã os catimbozeiros me dando cantigas" (22/12); "também que nem ontem e anteontem dia completamente besta. Todos o homens combinados vir aqui em casa cantar, falharam" (2/1); "com um velho pernóstico que sabe o Fandango" (4/1); "procurando um Maracatu" (8/2); "melodias de carregar piano" (14/2) etc. etc. as referências se multiplicam pelo diário.

E se o roteiro era ditado pela pesquisa, indiretamente outros cicerones se imporiam - cantadores, rabequistas, coqueiros, emboladores, mestres, catimboseiros, marujos, turcos e pastorinhas dariam ritmo e rumo na viagem -; cicerones involuntários de um turista resolvido a segui-los de perto; cicerones imprevisíveis, às vezes intoleravelmente atrasados, inconstantes, que encantavam e comoviam o turista aprendiz ao mesmo tempo em que o levavam ao desespero e à impaciência, mestres que tardavam, falhavam, desperdiçavam-lhe o tempo, desviando-lhe, exibindo-se, escapando. Figuras às vezes irresistíveis, como o cantador Chico Antônio, verdadeiro trovador medieval na arte de chegar e de partir (Idem, 12/1/1929). O artista popular e os amigos revezavam-se, assim, no papel de cicerones.

Pelo inventário vê-se que o tempo principal foi dedicado à pesquisa. Não que o viajante se encontrasse no profissional ou cientista (Idem,
15/12/1928, 8/1/1929). Há anos Mário percebera o conservadorismo das visões românticas e regionalistas do folclore (Lopez, 1972, pp. 75-84). O tédio com os levantamentos, evocação do gabinete, se entrevê na rejeição aos dados pelos dados na procura dos sentidos contemporâneos da produção do povo. Investirá assim na compreensão crítica das duras condições de vida das populações de pobres - suas casas, roupas, comida, trabalhos, salário, crenças, ânimo, saúde. Vêem-se ecos de um contato do escritor com o marxismo latino-americano na defesa comovida e impaciente da rebeldia primitiva e do gangaço contra a incapacidade federal de resolver as mazelas do campo e da seca: "não é possível pregar revolução nesse país. Na certa que haverá traidores. O que nós carecemos é dum gangaço secreto, matando friamente fulano que é gatuno, fulano que é burro, fulano que é abúlico, assim" (O turista aprendiz, 22/1/1929).

A chegada pelo mar se deu no Recife. Dali em diante seguirá por terra. Milhares de quilômetros entre 10 de dezembro e 24 de fevereiro do ano seguinte. A mudança de veículo, do mar para a terra, marca um corte. Nestas três cidades, doravante aproximadas pelos trens, automóveis, pelas redes de amigos e manifestações do povo, os atributos fundamentais da segunda viagem surgirão. Em Natal, João Pessoa e Recife, cidades onde o viajante demora e não apenas aporta, bases principais dos levantamentos, é dominante o interesse pela música, dança, poesia e religiosidade populares. Nelas, Mário partirá freqüentemente aos arredores e bairros pobres, assim como às praias e à binterland, sertões e cidadezinhas do interior de onde provinham os migrantes. Também o patrimônio histórico entrará nos seus circuitos: os centros velhos, a arte sacra e a arquitetura colonial, nele ativando também o crítico, desde jovem disponível para a arte do passado. Em suma, cultura e festas populares, arte e história, mas também a comida e a bebida locais, as praias e os banhos de mar, completariam este roteiro até então pouco usual de introdução às cidades nordestinas.

Em Natal, terá como anfitrião Câmara Cascudo, cronista da cidade desde 1918. Com ele, as afinidades de correspondente já haviam se transformado em forte laço de amizade. Além dos in- 
teresses pelas coisas de folclore, Mário nele encontraria um fiel companheiro de causa, que publicara meses antes do embarque do poeta paulistano para o Norte, na Revista de Antropofagia, uma crônica modernista sobre Natal (Cascudo, 1928), logo também interessando-se pelo debate local do urbanismo. ${ }^{31}$ Passará na Vila Cascudo o período mais longo da viagem: "moro no bairro alto do Tirol".

Pelas crônicas e anotações de viagem, Natal é onde o viajante melhor se encontrará: "é um encanto de cidadinha clara, moderna, cheia de ruas conhecidas encostadas na sombra de árvores formidáveis. De todas estas capitais do norte é a mais democraticamente capital, honesta, sem curiosidade, excepcional nenhuma". Não possuía os encantos de Belém, do Recife, de Salvador "um bocado egoísticos. Coisa pra viajante visitar e gostar, originalidades que tornam estas cidades exóticas até mesmo pra brasileiro" (O turista aprendiz, 16/12/1928). O seus encantos, ao contrário, recusavam identidade de turista. Em Natal, mal desembarca e já se encontra "em plena city": intimidade imediata, embalada ao som dos cantadores, as suas praças evocavam as praças florentinas - "destinada aos cantastorie, onde eles dedilhavam o alaúde, a trompa marinha cantando sem mais fim. Aqui também". Liricamente democrática, na cidade nordestina "O vento canta, os passarinhos, a gente do povo passando. O homem que leva e traz as vacas daqui de perto, não trabalha sem aboiar... Aqui em casa também. Todos cantamos" (Idem, 15/12/1928). A imagem recorrente é mesmo de uma cidade popular, psicologicamente democrática com suas ruas abertas, muita luz e vento, "conforto praceano", encanto honesto, "ar de chacra que a torna tão brasileiramente humana e quotidiana como nenhuma outra capital brasileira". Dividida entre o moderno e o popular, mais do que qualquer outra, Natal seria mapeada urbanisticamente: o rio, as praias, os largos, as ruas e as avenidas, a distribuição dos usos e das classes, os bairros pobres, nunca miseráveis, "sem aquela presença forte de tristura dos mocambos recifenses", os bairros ricos sem "nenhuma nota de novorico", que "têm aquela humanidade feliz de certos bairros burgueses de S. Paulo" (Idem, 16/12/1928).
Mais do que isso, em Natal, como em São Paulo, não havia impedimento ao crescimento e à reforma: "cidade mocinha, podendo progredir à vontade sem ter coisas que dói destruir"( Idem, 29/12/1928). Bem diferente da Bahia, por exemplo, tão abalada pelos prós e contras das demolições (cf. Peres, 1987; Pinheiro, 2002):

[...] creio que vou achando uma graça dolorida nos partidários e antagonistas da destruição [...]. O problema da Sé da Bahia está mas é enunciado errado. É muito mais grandioso do que a derrubada ou não derrubada dum casarão pra alargamento de rua. O próprio centro urbano da cidade alta é que se tem de resolver se é prático ou não ficar onde está. Todas aquelas ladeiras, quedas de sopetão, torceduras de terrenos são absolutamente contrárias a qualquer norma utilitária de urbanismo contemporâneo ( $O$ turista aprendiz, 29/12/1928).

É o que lembra Mário naquele mesmo dia. Em Natal, o modernista e preservacionista ampliava o enfoque do patrimônio para o urbanismo, forçando uma passagem da discussão do monumento para o centro histórico e dele para as funções de centralidade. Em Natal, ao contrário, a cidade era campo aberto ao futuro:

[...] o que é velho não é... antigo, pouco ou nenhum valor tem. Natal tem seu futuro enorme como banco de riquezas fundamentais [...]. As tradições dela são todas móveis, danças, cantorias. Essa felicidade americana de Natal está se objetivando neste momento com a inauguração do Aero-Clube. [...] Os aeroplanos estão pintando o sete no ar. [...] nenhuma Europa tradicional, te dana! (Idem, 29/12/1928).

Sem tradições imóveis, em Natal reencontrava-se - nas manifestações populares, como veremos - o sentido positivo da tradição contra os casos prejudiciais, como a carroça do rei da Inglaterra e o estilo neocolonial na arquitetura. Natal era um sonho americano de cidade: sem passado fixo, espraiando-se no espaço, campo aberto à aviação e à expansão. Com efeito, os diários revelam a importância do aero-clube e da praia nos roteiros (Idem, 15, 25, 29/12/1928). De um lado, uma 
Natal copacabanizada, de outro, o "cais da Europa", ${ }^{32}$ aberta aos raids internacionais: as observações faziam eco ao intenso debate urbanístico dos anos (1924-1930) Omar O'Grady (Dantas, 2003), o prefeito aviador, engenheiro formado nos Estados Unidos e inventor de Areia Preta.

Mas o fato é que o turista dedicaria poucas linhas à cidade oficial, civilizada, toda ela uma conquista nova da década de 1920 (Idem). É flagrante a sua predileção pela outra parte da cidade, baixa, menos visível, mais escura, que às vezes se imiscuía pelas ruas principais da Ribeira comercial, ou dos bairros novos da parte alta, com as brincadeiras populares - os cocos, os pastoris e as marujadas. No litoral, em Areia Preta ou Redinha, encontrava "sambas, maxixes, varsas de origem pura, eu na rede, tempo passando sem dizer nada" (O turista aprendiz, 30/12/1928). Nos bairros populares, em Rocas, sem muita luz e coberto de coqueiros, antigamente tomado de casinhas de palha, valhacouto de criminosos e facínoras da cidade; no caminho do Areal,

[...] morro cheio de casas proletárias alinhadas numa rua bem larga rodamoinhando no vento. Por ali moram embarcadiços, catraieiros, operários das docas. [...] A rua está viva. Sons de pandeiro, pessoal se chamando, um tambor mais pra longe e na porta da venda um ajuntamento. Vão ensaiar a Chegança pro Natal (Idem, 18/12/1928).

Eram nesses bairros pobres, "sem iluminação, sem bonde, branquejado pelo areão das dunas", que Mário encontrará o catimbó, seus mestres e feiticeiros. Centros de uma cultura alegre da cidade, exterior, informal, móvel, imperfeita, carnavalizada, sugerindo alteração nas relações entre o popular e o moderno, revelando uma arte viva, a comunhão com o público, prescindindo de categorias eruditas.

Encantamento estético que de resto não desdenha da crítica social: pois "se saúde, facilidade, bem-estar fosse deduzível da alegria, o proletário nordestino vivia no paraíso" (Idem, 1/1/1929). E se não é o caso, há que se conhecer melhor o seu mundo e não apenas as suas obras de cultura. Por vezes, a apresentação dos meios e dos quadros de vida da população pobre aos leitores paulistanos será minuciosa:
Em Natal, os bairros onde param os proletários são principalmente dois: o de Alecrim e Rocas. Também nas alturas da Lagoa Seca mora bastante operário que devido a careza do bonde, come areia todo o dia pra atingir o centro da cidade, longe. [...] Não há mocambo. O mangue fica da outra banda do Potenji, onde ninguém não mora. No Alecrim como em Rocas as casas são cobertas de telha e muitas de tijolo. Se enfileiram pequititas, porta e janela de frente, em avenidas magníficas, todas com o duplo de largura da rua comum paulistana. [...] A comida é bem monótona. Farinha, feijão e carne-seca. [...] A maioria trabuca no algodão e no açúcar. Descalços no geral, calça e paletó de algodãozinho, às vezes sem camisa, que calor! Cobrindo a cabeça com o chapéu de palha de carnaúba, muitas feitas de forma fantasista, muito engraçada. Pronto: estão trabalhando. Quando senão quando uma cantiga (Idem, 2/1/1929).

Resumo sociológico da vida pobre na cidade que se completará em empatia com a visão das condições de vida no campo. Se o embarque para o interior se justifica pelo aprofundamento dos levantamentos culturais, no contato com as regiões do açúcar, do sal e do algodão, a perplexidade irá evoluir em revolta: "está com jeito da gente andar turistando pelas Áfricas e Ásias do atraso inglês, francês, italiano, não sei quem mais!... todos os atrasos da conveniência colonial" (Idem, 8/1/1929). Indignação anticolonial contra a exploração econômica do trabalhador eternamente forçado ao ir-evir do investimento capitalista e da seca. Se antes levavam o migrante para o Norte inundado de borracha, agora o impeliam para o Sul industrial. Se para os sulistas era bom, a seleção depauperava o Nordeste, alienando a região de seus moços fortes e arranjados, que se desnudavam até do sentimentalismo ao partirem. Na usina de sal, a remuneração "custa bem a gente distinguir o que seja crime nesta sociedade em que vivemos" (Idem, 18/1/1929); nas estradas, retirantes; "a viagem virou desgraçada" (Idem, 19/1/1929); Euclides da Cunha estava errado, "não se trata de heroísmo não. Se trata de miséria" (Idem, 21/1/1929).

Também na Paraíba, a estadia foi prioritariamente dedicada ao trabalho. No dia seguinte à sua chegada, A União revelou saber os seus motivos: 
"Fiel ao seu programa de idéias o ilustre intelectual paulista veio ao Nordeste com o fim de coligir mais documentação para sua obra do folclore musical do Brasil". ${ }^{33}$ E de fato, pelas notas de viagem, os passeios pela cidade, por Tambaú e o centro, quase somem meio ao trabalho intenso e reservado, alternado com algumas saídas de reconhecimento pelos bairros populares como o Róger e Cruz de Alma, para ver lapinhas e caboclinhos. Demorou até tomar contato com a cidade. A novidade desta vez foi o patrimônio histórico:

[...] chego no pátio de convento de S. Francisco e paro assombrado. [...] Do Nordeste à Bahia não existe exterior de igreja mais bonito nem mais original que este. E mesmo creio que é a igreja mais graciosa do Brasil - uma gostosura que nem mesmo as sublimes mineirices do Aleijadinho vencem em graciosidade (Idem, 30/1/1929).

A edificação colonial desperta agora o crítico que lê a obra. Arquitetura, pintura, escultura, talha, azulejaria, João Pessoa devolvia ao folclorista a vocação do historiador crítico à procura da singularidade, da autenticidade, das atribuições, filiações, técnicas.

Bem maior do que Natal, a cidade lhe pareceu bem menos compreensível: "das mais enigmáticas que já encontrei, e não sei resolver se é bonita se é feia". Apesar de recebido e conduzido por intelectuais ligados à revista Era Nova, Joaquim Inojosa, José Américo de Almeida, Ademar Vidal, Silvino Olavo, a distância certamente interferiu na fruição. Cidade velha e nova, colonial e moderna, desmantelada e sem o aproveitamento urbanístico das perspectivas. Observação pertinente de quem a visitava em tempos de saneamento e obras no porto, que atingiam desmesuradamente o tecido tradicional, abrindo, alargando, extendendo ruas e avenidas, desapropriando e demolindo prédios históricos e até igrejas como a do Rosário dos Pretos e a de Nossa Senhora da Conceição (Trajano Filho, 2003). O resultado era visível ao turista: pouco verde, condução difícil, calçamento antiquado, antigüidades arquitetônicas esplêndidas misturados a edifícios novos, mocambos e bairros operários "desruados".
Quanto ao Recife, porto de desembarque e de embarque no Nordeste, surgiu no roteiro na chegada e na saída. Já no dia 10 de dezembro de 1928, o poeta Ascenso Ferreira lhe esperava no cais. Ponto final da cabotagem, marcava reinício de viagem de trem, de carro, em terra firme ou pés no chão. Sem demora, deixava-se para trás a lesma de vapor. Em nenhuma ocasião, a vista da cidade desde o mar mereceria comentário. Nem agora, nem antes quando a caminho da Amazônia em 1927. À diferença de Vitória, do Rio de Janeiro, da Bahia, à distância talvez a cidade não suscitava curiosidade (A. Costa, 1928). Já na viagem de 1927, resumira-se no horizonte a figura de Ascenso Ferreira, autor de Catimbó em pessoa, e de Joaquim Inojosa, promotor do futurismo no Nordeste, conhecido de Mário desde os tempos de Klaxon, autor do manifesto $A$ arte moderna publicado no Recife em 1924. Com eles, foi "Recife e mais Recife dia inteirinho, aliás muito prazer" ( $O$ turista aprendiz, 15/5/1927). Sabemos que naquele único dia de 1927 passou a manhã em Boa Viagem, tomou água de coco gelada, almoçou no Leite, ouviu versos na casa de Ascenso, jantou no Leite, "fatalidade recifense, como o Butantã paulista", e de noite, "Boa Viagem, ao luar sublime". Pendulando entre a praia e o restaurante do bairro de Santo Antônio, no meio do passeio a poesia: o passeio, a companhia, a poesia e a fadiga, a isso resumiu-se o primeiro dia do turista no Recife. O segundo foi só na volta do Norte, e no dia 8 de agosto Mário encontrou o Recife "num sol esplêndido". Saiu com os companheiros de bordo, entre os quais certamente Olívia Guedes Penteado e as duas adolescentes. Foi ver o peixeboi - no Parque Amorim, e não no Derby, como se sabe - para despedir-se talvez das correntes do Amazonas. Jantou outra vez no Leite e, uma vez sozinho, pôs-se a buscar Inojosa. Nada dele, nada de Ascenso. Sabe-se que este também o procurou naquele dia - que "teve a decepção de não ver você", escreveu-lhe Manuel Bandeira dias depois ${ }^{34}$-, que começou a chuviscar fino e frio e que, sem dinheiro, desencontrando-se do amigo, deu com o rio. Voltou em sentido contrário e, de repente, deu com o rio de novo. Já não sabia para que lado ir. Perdera-se no centro daquela cidade de 
quase 400 mil habitantes. O centro estava deserto, sentia frio, homens retardatários passavam: "Penso que vêm me prender. Não, vêm me roubar. Dou uma risada alta. Os homens me olbam meio assustados" (Idem, 8/9/1927). Típicas experiências de estrangeiro, o passeio tropical e a aflição do extravio, não houvessem sido motivadas pelas afinidades modernistas anteriores à expedição etnográfica. Turista recatado e dócil, a cidade não fazia sentido sem seus amigos. Cais e Leite, rio de um lado, rio de outro, água de coco e peixe boi, praia e rua deserta fundiam-se à experiência do encontro fraternal, tanto mais nesta cidade tida, como São Paulo para ele em 1920 (Lopez, 2004), por não se entregar imediatamente ao estrangeiro: seu melhor encanto consistindo "mesmo em deixar-se conquistar aos poucos" (Freyre, 1964).

\section{O turista como crítico: arte e sociedade}

No dia 10 de dezembro de 1928 hospedouse no modesto Hotel Glória, na rua Nova, bairro de Santo Antônio, plena cidade maurícia; almoçou com Ascenso e sua esposa Stella Gris, visitou igrejas, tomou água de coco e encontrou Inojosa. O jantar foi na casa do poeta, com Manuel Bandeira, que chegara em Recife havia quase um mês. À noite sairia em passeio pelas "partes velhas de Recife", certamente acompanhado dos anfitriões pernambucanos. Já nesse primeiro dia, saltou aos olhos as velhas igrejas e os conventos da cidade, que, até mais do que na Paraíba, iriam lhe roubar muito tempo. Perambulando pelo centro histórico, atravessando pontes e freguesias, becos e travessas, entraria em cada largo, cada pátio, claustro e interior de igreja, para ver seus azulejos, mobília, altares, entalhes, imagens e principalmente sua pintura. Na Ordem Terceira de São Francisco, no Recife, no Convento de São Francisco, em Igaraçú, no Convento de São Francisco de Olinda (O turista aprendiz, 19/2/1929) desde o início os pintores lhe entusiasmaram: "talvez os melhores da Colônia" (Idem, 11/12/1928). É notável como o contato com o passado, ao lado da comoção habitual, foi traduzido nos termos de um reconhecimento do fazer nas diferenças de desenho e execução, em suas marcas de contraste. Atitude emancipada do crítico que ali confirmava o interesse da arte franciscana do Nordeste, em contraste com o silêncio ante a pintura modernista então nascente.

Mais do que isso, fosse em Olinda, em Igaraçu ou no Recife, a cidade era principalmente pontuada pelos monumentos ainda mal catalogados de arquitetura e arte sacra do período colonial. O admirável convento de São Francisco, o bem inferior mosteiro de São Bento e a Sé em Olinda, essa "merda exterior", a pobrinha São Cosme e São Damião e o maravilhoso São Francisco em Igaraçu, a Conceição dos Militares, com o luxo barroco e notável painel historiado de Guararapes, a magnífica igreja do Carmo, os painéis magistrais da Madre Deus, no Recife, interesse menos de turista que de preservacionista, em plena era de remodelação. Depois da escandalosa demolição da Igreja do Corpo Santo do Recife (Lubambo, 1991) e da recente desfiguração da Sé de Olinda e da matriz de São José - reformadas à "gótico de fancaria", safadezas de restauração eclética no dizer daqueles que então se preocupavam com o caráter da cidade ${ }^{35}-$, era de se preocupar com os velhos templos. O alerta vinha de Manuel Bandeira, que dias antes saíra no jornal dirigido por Gilberto Freyre em defesa da igreja da Madre Deus: "as ruínas apenas entristecem. Uma restauração inepta revolta, amargura, ofende"; que se deixasse a Madre Deus em seu cantinho de cais, "ela que não atrapalha o tráfego urbano, que não aparece aos turistas em trânsito" (Bandeira, 1928b). A questão tinha alcançado tal repercussão que mesmo um engenheiro como José Estelita, desde cedo vinculado aos maiores inimigos dos templos coloniais, à engenharia portuária e à técnica urbanística, que seria elevado na década de 1930 à liderança profissional da importância do paulista Prestes Maia, no mês seguinte partiria contra os furores modernistas (Estelita, 1929). A campanha jornalística no Recife era então capitaneada por Freyre em A Província: Defender as igrejas aliava-se à defesa do Recife "sujo de velhice", ${ }^{36}$ de seus becos mouriscos, dos arcos da Conceição e de Santo Antônio, do cais da Lingueta, das velhas gameleiras. Tratava-se na verdade 
de preservar toda uma ambiência imaginária e evocativa de modo a impedir o desenraizamento dos nativos ${ }^{37}$ em favor dos urbanistas. Para estes, o novo Recife era

Uma delícia de regularidade. Um Recife geométrico como um jardim do Loire. Casas dispostas como um menino dispõe soldados de chumbo para batalhas de brinquedo: em fileiras regulares e hirtas. Árvores aparadas igualmente como o cabelo em escovinha dos órfãos e dos presos. As ruas todas da mesma largura. Nenhuma rua torta. Nenhuma igreja a quebrar a linha reta das ruas. ${ }^{38}$

Com "suas avenidas orgulhosamente modernas", a cidade estava ameaçada de perder a fisionomia de origem: "não sei quais as linhas do plano Agache para a remodelação da cidade. É de desejar que não dêem gordura ao Recife. Ela deve continuar magra, reservada e difícil" (Bandeira, 1928a).

Não obstante o intenso debate local do urbanismo (Moreira, 1994; Pontual, 2001; Outtes, 1991; Lira, 1995, 1997), afora o cuidado com as igrejas, Mário de Andrade não teria muito a dizer sobre a cidade. Ao ar livre, foi quase lacônico. É verdade que fotografou muito: em uma das fotos pôs a legenda - "Beco menor do mundo, Recife, 12/12/1928"; na estadia de fevereiro registrou o bairro do Recife, a praça do governo, a rua Nova, o largo de São Pedro em Olinda, tendo conservado também inúmeros cartões postais com vistas panorâmicas da cidade à beira-rio. ${ }^{39}$ Só uma vez, em Igaraçu, com Ascenso, é que se mostrou sensível à forma urbana: "A gente desemboca num passado evocador e segue mais ou menos assustado por aquelas ladeiras, ruas tortas, praças ocasionais, nascidas duma fantasia de arruamento, bem de gente com vagar" (O turista aprendiz, 11/12/1928). Contudo duas situações urbanas despertaram-lhe do passado: a vista da cidade desde o rio, e os mocambos de praia, beira de estrada e beira de rio. Já na tarde do dia 12 de dezembro de 1928, Mário foi levado por Bandeira para um passeio de lancha pelo Capibaribe com Gilberto Freyre. A bem da verdade, o passeio fluvial tornara-se um gesto de resistência ao urbanismo de boulevares e avenidas, na mesma linha de valorização dos benefícios da sombra fresca e da rua tor- ta e acolhedora da flâneurie tropical. ${ }^{40}$ Tratava-se de uma entre as várias heranças da boa cidade que as décadas pós-Vauthier e Pereira Passos haviam descartado. O fato é que Mário e Bandeira, ao lado de Gilberto, empenharam-se em fotografar a experiência fluvial e as cenas ribeirinhas que dali descortinavam. As de Bandeira, sabemos que não prestaram. Das de Mário, conservam-se algumas cenas urbanas, da rua da Aurora, no encontro dos rios. Foram essas as impressões registradas:

[...] passeio de lancha pelo Capibaribe, maravilhoso, com vista da cidade, depois dos arrabaldes, o da Madalena, com os velhos cais das vivendas das famílias ricas antigas, alguns deliciosos de monumentalidade simples, os coqueiros sempre espantados. [...] Voltamos numa conversa mais baixa, recontemplando em azul-negro de desenho, a paisagem colorida de já-hoje (O turista aprendiz, p. 347).

A nostalgia que inspirava a expedição alimentava a imaginação.

Mas, ao longo do Capibaribe, como em toda parte, também os mocambos lhe desviaram a atenção do trabalho e dos amigos para a cidade. Posou na frente de algumas dessas casinhas de palha de Boa Viagem com Ascenso e Inojosa em 1927. No ano seguinte, a caminho de Igaraçú, reparou-as nas bordas da estrada, evoluções do mocambo (Idem, 11/12/1928), que produziam variedade e graça. Mas foi no passeio de carro em Boa Viagem na noite seguinte que as luzes improvisadas dos mocambos the causou sincera comoção: reflexos

[...] que nem fachos revirados. A imagem ficou ruim... Não são fachos não; é mais a água doente chupando tudo, chupando a vida da luz, chupando o sangue das gentes habitando aquilo, como quem se aboleta no socavão da morte... pra viver. É triste, bem triste... (Idem, 12/12/1928).

A visão turvada pela cena, o fôlego dissipado pediam explicação. É notável que Mário tenha sabido nesse ponto se afastar das posições incendiárias e românticas assumidas localmente na querela dos mocambos que atravessou a década 
de 1920, mobilizando a opinião de homens da terra como Gilberto Freyre, Mário Sette, Salomão Filgueira, Eduardo de Moraes, ou visitantes como Ribeiro Couto, Nestor de Figueiredo, Alfredo Agache ou José Mariano Filho, que se dividiam na condenação e no elogio dos mocambos: ${ }^{41}$ "foi a atração da cidade, foi essa coisa infeliz", Recife, "a praça linda do nordeste abicada no entresseio do Capibaribe e Beberibe, contavam tanta coisa dela!... Tinha cada igreja, Deus! Era ouro só... [...] Tudo fácil, médico, dinheiro, tudo fácil" (Idem, 12/12/1928). Atrativos e facilidades de centro metropolitano na região das secas que tinham força encantatória, sortilégios que iludiam os retirantes, forçados a se aboletarem "na barra da cidade" em mocambos tão desgraçados, nunca pitorescos, quanto a seca e a miséria dos arranchados à beira dos açudes federais.

É provável que a diluição das imagens urbanas no universo pictórico das igrejas, na imobilidade dos claustros, altares e sacristias, no deslocamento de automóvel e lancha reverberasse em sua atitude de contemplação e recolhimento. Sinalizando talvez uma predileção na viagem etnográfica pelo que contradizia e não resolvia o processo de modernização e urbanização. No Recife, este humor chegaria ao abismo, e a entrega final do turista ao carnaval, à embriaguês, à droga e ao êxtase na cidade parece até um remédio, uma consolação. Pois o Recife para tal tinha

[...] uma invenção maravilhosa: o frevo. [...] Caí nele. Aprendi o Passo (reparem a maiúscula). Nunca me ri tanto e gozei a felicidade de reconhecer que ante o convite rítmico-dinâmico do Passo, desapareciam até as conveniências do meu tradicional artritismo paulistano" (Idem, 16/2/1929).

A queda por demais na frevoeira, o entregarse aos porres e às loucuras com Ascenso e Cícero Dias, a busca frenética dos maracatus depois das cinzas, emergiriam inclusive nas mil fugas e entradas pelos arredores do Recife e na Zona da Mata. Consolação e convalescença. Os engenhos Batateira e Martinica, Escada e Cabo, Boa Viagem e Olinda, idas e vindas que embaralhavam em ponto de despedida os sentidos dessa cidade miserável, redimindo-se do turista com seus cantares e brisas, linhas de catimbó e Marias Joanas, Bois e mãos de vaca, empadões de pitu e fortes verdes e azuis. Tendo começado a estadia final de quase duas semanas no meio de frevo, serpentina, cocaína e éter, Mário agora se despedia da cidade com "um último passeio sentimental, a pé” por suas pontes e cais. No dia 21, já acordava em Maceió. Uma notícia do crítico musical Ernani Braga no Recife dá conta do peso de sua bagagem:

[...] volta a São Paulo levando mais de oitocentos temas colhidos diretamente no rio Grande do Norte, na Paraíba e aqui em Pernambuco. [...] É insaciável. Visita cidades e sertões, engenhos e mocambos, igrejas e antros. Conversa com acadêmicos, ouve trovadores populares, discute com os intelectuais, observa os tipos de rua. Onde possa suspeitar um filão precioso, lá estará, firme e atento, sem medir tempo, distância ou sacrifício. É de uma resistência milagrosa. ${ }^{42}$

\section{Itinerários de civilização e dois contrários}

Qual o fio condutor das viagens de Mário de Andrade pelas cidades do Nordeste? O propósito etnográfico de estudo das danças dramáticas são o mote, e lhe conduzem em toda parte rumo ao povo comum, às suas manifestações de cultura e alegria, mas também a seus lugares de moradia, hábitos, meios de vida e formas de trabalho. Tal o elemento mais contínuo ao longo de toda essa viagem: a coleta e o aprendizado junto ao povo. Isso é particularmente evidente entre Natal e João Pessoa, e nas incursões pelas matas e sertões fica a impressão que o predomínio da razão etnográfica também será responsável pelo tom lúdico, afetivo e crítico do que relata. Mas a vivência das cidades produz diferenças bem marcadas. Em João Pessoa, a herança artística e o patrimônio colonial se apresentam em seu itinerário e conduzem o viajante de volta ao mundo europeu, que se no Nordeste desperta algum interesse, ao contrário da Amazônia, é ali posto entre parênteses na ótica do erudito. Em Mamanguape, Igarassu, Olinda e Recife, os marcos monumentais dão as principais balizas da viagem. É interessante perce- 
ber que entre essas cidades há uma gradação. Natal é aconchegante, democrática, aprazível, moderna e popular. João Pessoa, indefinida entre o antigo e o novo, pede ao visitante uma atitude mais reservada, preventiva. Recife, metrópole regional abarrotada de riquezas de outras épocas, tradicional, hierárquica, mais complexa, suscita ao mesmo tempo desnorteio e indignação, sentimentos que apenas os dias de torpor, carnaval e intensa confraternização pública poderiam abafar no viajante. É lógico que em toda parte é decisiva a afinidade dos amigos cicerones, que selecionam os lugares e objetos e ajudam a compor seus circuitos. Mas a atitude vagueante do estrangeiro escapa aos imperativos convencionais. Mário novamente ataca as representações colonialistas, ilustradas e românticas que se espalham pelo Brasil civilizado, indiferentes aos sofrimentos reais de seus habitantes. Incide também contra um conceito de viagem como regresso ao maravilhoso, ao bárbaro pitoresco, aos exotismos tropicais até o final do século XIX (Leite, 1996), praticando o àvontade, a descontração, a liberdade na tentativa de confundir-se com o outro. Por isso foge também ao turismo em sua forma mercantil, tantas vezes ironizado ao longo da viagem, na sua pressa e fixação do estereótipo para inglês, na sua sanha consumista pelo que se dá por visto de primeira, nos seus trajetos preestabelecidos, no seu temor ao desvio, ao acaso, ao extravio, à entrega às emoções, ao improviso e a solicitações locais.

De fato, desde o final do século XIX os itinerários turísticos na região ainda pareciam se pautar pelos elementos de contemporização com a civilização européia, típicos dos circuitos habituais dos viajantes oitocentistas, avidamente procurados ou lamentados quando não encontrassem na terra estranha: "ni gondoles, ni gondoliers, ni doges, ni dogaresses" (Nery, s.d); "fortunatelly, there are forks manufactured exclusivelly for use in this process [de comer mangas] which would else offer a problem to table manners and dignity" (Wright, 1901, p. 310). E oferecidos como atrativos pelos nativos: "um cunho europeu" (Dias, 1904); muito bem servida de todas as facilidades (Vianna, 1900). Interessante observar nesses roteiros a rejeição e ao mesmo tempo a presença luso- colonial e popular, que efetivamente cedia no avanço em toda parte ante os embelezamentos, os melhoramentos, as higienizações e as modernizações das poucas e grandes cidades brasileiras. O que devia ser um problema para seus promotores e visitantes. Não só numa Recife, onde apesar de seus fundamentos serem "devidos ao gênio marítimo dessa raça de amphibios, a gente hollandeza" (Dias, 1904), a colonização portuguesa havia sacrificado "toda noção de higiene arquitetural" (Orlando, 1908, pp. 58-59), mas também em uma Natal, onde no começo do século XX a historiografia e a corografia da cidade revelavam atraso, acanhamento e mesmo irrelevância desde a colônia. ${ }^{43}$ É sintomático que ainda em 1924 um viajante potiguar na Paraíba tenha procurado na cidade justamente aqueles ícones de modernidade celebrados pela administração Guedes Pereira, o "Pereira Passos paraibano". ${ }^{44}$

O itinerário de Mário de Andrade no Nordeste andava em outras direções, pois justamente iluminava os objetos que as imagens oficiais e comerciais há muito vinham insistindo em suprimir das cidades. Ainda em 1927, 1928, 1929, o viajante precisava aprender a driblar as boas maneiras turísticas, os exemplos e guias de viagem disponíveis nessas cidades que apenas começavam a ingressar no circuito comercial do turismo. Talvez porque a sua viagem se situasse entre a missão cultural, a campanha etnográfica, a visita aos amigos distantes e às terras inspiradoras, Mário tenha sido capaz não apenas de abarcar aquilo que bem depois se tornaria mercadoria turística - a praia, as festas, o folclore, a comida típica, os coqueiros e a água de coco, a arte colonial e o monumento histórico mas também de lograr, em sua fruição, transcendêlo na predisposição à aventura e à empatia com o outro, na prática do "despaisamento". O que isso significava para ele? Viajar incluía transitar descompromissadamente pelas rotas e lugares percorridos à procura das sensações e de incidentes peculiares, atentar para uma mudança na luz, um momento de cor, o brilho das coisas, as plantas e moitas, os animais, um entardecer distinto, as manhãs, o vento, o bater do vento úmido, as frutas. Significava também compreender como viviam aqueles lá, sobretudo os que pareciam tão distantes de seu ponto 
de partida: sitiantes, camponeses, proletários, migrantes - observar como falavam, a maneira de contar e de sorrir, de cantar e de dançar, de andar e trabalhar, de morar e cultuar. Despaisar-se era poder sentir-se em casa no outro. É verdade que Mário bem sabia que o cronista-turista do século XX não tinha mais terras a desbravar ou de que fincar posse. Mas, a alternativa pela incorporação do Brasil à sua errância - pela via da cultura popular subjacente às normatizações civilizatórias desta sociedade profundamente desigual - tensiona as representações de cidade dominantes ao longo de toda a Primeira República: "civilização brasileira", pensava ele, que consistia "em impecilhar as tradições vivas que possuímos de mais nossas" ( $\mathrm{t}$ turista aprendiz, 6/1/1929).

É verdade que, também na década de 1920 , ascendia por aquela parte do país uma atitude regionalista aparentada, ainda que altamente matizada em termos intelectuais, estéticos e políticos. Algumas vezes em tênue contato com o modernismo da Semana e com as tendências mais recentes em literatura e antropologia (Cardozo, 1985; Barros, 1975), manifestava localmente uma inclinação para os valores cotidianos da cultura; tocada de pragmatismo e sentimento, e tendo como pretensão resistir tanto ao ufanismo da província como à vaga uniformizadora da civilização, defendia a simplicidade e a diversidade dos valores regionais brasileiros. Gilberto Freyre, nesta linha, foi o seu mais ilustre representante.

Com efeito, entre os conteúdos programáticos postulados pelo I Congresso Regionalista do Nordeste, realizado no Recife em 1926, incluíamse coisas como o "aspecto turístico e valorização das belezas naturais da região", as "tradições da cozinha", a "defesa da fisionomia arquitetônica do Nordeste", de "parques e jardins nordestinos", do "patrimônio artístico e dos monumentos históricos", a "reconstituição de festas e jogos tradicionais". ${ }^{45}$ Ou seja, muita coisa freqüentemente desprezada parecia começar a merecer preocupação oficial. Se essa nova opinião regionalista não era imune ao conservadorismo - e ao ânimo separatista - de uma elite que se via empobrecida e abandonada à própria sorte, na nostalgia do passado senhorial em decomposição, o movimento seria marcado também pela forte presença de setores urbanos, ${ }^{46}$ revelando ambigüidades no trato das questões modernas de arquitetura e urbanismo (Lira, 1997). A despeito, porém, da componente futurista (Joaquim Inojosa) ou modernizadora (Amaury de Medeiros, Otávio de Freitas, Gouveia de Barros, Antônio Jannuzzi) entre seus participantes, a interpretação predominante do movimento e de seu conceito de "tradição viva" não foi de todo estranha ao que pouco depois Mário de Andrade defenderia no Nordeste, por mais que houvesse resistências à leitura modernista da causa local: "como é que um nordestino de vida assim vivida a poderá desprezar por um vago brasileirismo?", ${ }^{47}$ indagava Gilberto Freyre a Guilherme de Almeida em sua marcha da brasilidade de 1925.

Sabe-se que Mário de Andrade não via com muito entusiasmo o regionalismo pernambucano, mas a julgar por seus interesses contemporâneos uma intervenção sua no evento não teria sido incompreendida. De fato, em 1925, ele tomou conhecimento do programa do congresso e até se entusiasmou, mas temia o aspecto desintegrante de sua insistência nas diferenças e nas curiosidades locais em uma nação já tão esfacelada: "acho o programa um pouco acanhado e além de regionalista, regionalizante o que é um perigo. [...] Porém de qualquer maneira que seja o Congresso é interessantíssimo e desejaria estar aî". ${ }^{48}$ Não por acaso, em Maceió foi conduzido por José Lins do Rego; no Recife, por Ascenso Ferreira; na Paraíba, por José Américo de Almeida; e em Natal, por Câmara Cascudo, o cicerone mais confiável, todos eles a seu modo integrariam o movimento. O próprio Freyre, líder inconteste, desde o começo da década já vinha aprimorando a crônica regional sob o influxo das ciências sociais e do modernismo, ${ }^{49}$ afastandose desde cedo da ótica provinciana.

Com efeito, nos "artigos numerados" publicados no jornal Diário de Pernambuco entre 1924 e 1925, o cientista social formado por Columbia, recém-chegado de seu grand tour pela Europa, batese por um conjunto de atributos característicos do torrão natal. "Venho revê-lo com outros olhos", anotou no desembarque em 1923, os olhos de "adulto viajado". O Recife a princípio não lhe desaponta, mas a viagem teria lhe custado muito 
caro, não apenas o desconforto com as mudanças, mas a pecha de estrangeirado:

[...] sinto é que sou repelido pelo Brasil a que acabo de regressar homem, depois de o ter deixado menino, como se me tivesse tornado um corpo estranho [...] um exótico, um meteco, um desajustado" (Freyre, 1975, pp. 127-128).

A acusação já lhe vinha sendo antecipada pelos mestres, protetores e amigos desde os Estados Unidos e a Europa preocupados com o desperdício de sua inteligência no Brasil, e particularmente no Recife. E de fato Gilberto hesitaria. Em 1924, escreveu em seu diário, "Sinto que meu ajustamento intelectual no Brasil é quase impossível. Experimento às vezes enorme vontade de voltar aos meus amigos de Columbia e sobretudo aos de Oxford - de Oxford e Paris" (Idem, p. 134). Se de fato havia muito de ressentimento e rastaqüerismo nos seus críticos, há na queixa uma confissão de inadaptado: de um lado, não consideravam a carga de sacrifício que lhe pesava; de outro, denunciavam a atitude cética do conterrâneo expatriado quanto às transformações recentes em sua cidade e seu país:

[...] se não me ponho em harmonia com o progresso brasileiro, nas suas expressões mais modernas, antes desejo voltar aos dias coloniais uma mentira - se isto, se mais aquilo, porque não volto aos lugares ideais onde me encontrava? (Idem, ibidem).

O fato é que tomou a decisão de ficar e identificar-se com "o que o Brasil tem de mais brasileiro" - em 1924, Gilberto anotaria, "minha decisão está tomada: é reintegrar-me completamente no Brasil" (Idem, ibidem). Familiarizando-se com a produção intelectual e artística nacional, visitando proustianamente engenhos e arquivos de família, viajando a Igaraçú, Olinda, Palmares, Tamandaré, adentrando matas e hospitais psiquiátricos, convivendo com as mulheres e a gente do povo em aventuras boêmio-sexuais e investigações etnográficas - "de bicicleta, venho fazendo meu fieldwork de estudante de Boas (Antropologia) e de Giddings e Thomas (Sociologia) [...]. Venho CO- lhendo muita nota de possível interesse sociológico e antropológico sobre a vida da gente das mucambarias do Recife". Era assim que o estrangeiro em sua terra tornava-se porta voz da origem.

Em abril de 1924, Gilberto Freyre escreveu no Diário de Pernambuco: "parece que temos vivido em duas cidades diferentes". A da infância, com seus cais, arcos, quiosques e gameleiras, e a modificada pela época de "aguda transição":

[...] uma cidade que parece estrangeira. Eu por mim já me sinto um tanto estrangeiro no Recife de agora. O meu Recife era outro. Tinha um "sujo de velhice" que me impressionava, com um místico prestígio, a meninice. O tempo o esverdeara todo de um verde que tinha o encanto de uma unção. ${ }^{50}$

Poucos os pedaços de pitoresco, os becos amouriscados, casas de beira arrebicada, janelas enxadrezadas nesse Recife simétrico e insolente, sem mistérios e furiosamente imitativo, hostil à memória: "o Recife novo me comunica um horrível mal-estar: o de estrangeiro na própria cidade natal. Doloroso tipo de 'deraciné". ${ }^{51}$

De fato, entre a infância e o presente, a cidade passara por um amplo processo de transformação de sua paisagem e engrenagens urbanas: de saneamento, com a demolição e alargamento de travessas e becos (Brito, 1942); no porto e área central, com suas ramificações ferroviárias, desapropriações, demolição de ruelas, pavimentações e o início da construção das novas avenidas principais da cidade, desenhadas como bulevares radiais, de esquinas angulosas e arrematadas secularmente de zimbórios e lanterins, partindo em perspectiva do marco zero à planície (Lubambo, 1991). Em 1912 e 1913, já se haviam inaugurado os primeiros edifícios novos, quadras inteiras do bairro do Recife assumindo o ar beaux-arts do Rio de Janeiro de Pereira Passos, esta cidade sem fisionomia própria, que se generalizava tiranicamente por todo o país; em 1913, seria demolido o Arco da Conceição; em 1917 o de Santo Antônio, espécie de barrière do outro lado da ponte Maurício de Nassau, ela mesma reinaugurada naquele ano em concreto armado (Lira, 1997). O ecletismo arquitetônico das novas casas de comércio e finanças unificadas pelo baronato local 
do açúcar representa a mesma vocação de parisianismo de burguesia litorânea (Silva, 1987).

Não foi à toa que na década de 1920 o entusiasmo modernizador suscitou a prevenção e o lamento regional:

[...] conservar uma cidade, seu pitoresco próprio, sua cor local, seu caráter, enfim, não quer dizer fechar-se às exigências da engenharia sanitária [...]: os reparos é que não devem exceder à crosta para ferir os valores íntimos, essenciais, da mesma paisagem". ${ }^{2}$

Cosmopolitismo barato animaria essa tendência de transição, diria o antropólogo; na febre do século despontavam o disparate, o arremedo, a caricatura. ${ }^{53}$ Estética do "Progresso", puro esnobismo clownesco que acatitava casarões e imperava: "estética fazedora de mercúrios, pontes maracajadas, leões e lagoas fingidas", ${ }^{54}$ "ramalhuda arquitetura bancária e comercial e oficial dos últimos anos [...]; a ganhar com vantagens de campeão irrivalizável o "Grand Prix" de Mau Gosto". 55

Tratava-se nitidamente de realinhar uma posição defensiva em sátira. Ainda que por bom senso: "sou de fato pela conservação de muita coisa velha do Recife [...]. Devo confessar que prefiro o "sujo de velhice" à tinta fresca" ${ }^{56}$ Defesa do patrimônio arquitetônico colonial e da permanência dos traçados urbanos em zig-zag; defesa dos valores de espontaneidade, de acaso e intimidade contra todo geometrismo, mas também das árvores tradicionais: "às árvores já tenho visto aplicado o corte radical à la garçonne"s7; defesa das plantas coloniais,$^{58}$ das árvores próprias à região, contra a terrível mania de reformismo, europeísmo, yankismo: "Não é pois de admirar que se tenha derrubado tanta gameleira, para plantar figueira benjamina - a indistinta, incaracterística figueira benjamina em que se vai tristonhamente estandardizando a arborização do Recife" ${ }^{59}$ O sentido ativo e não puramente nostálgico de sua intervenção na imprensa é patente no que escreveu acerca de urbanismo. Gilberto exprimiu abertamente sua oposição às máximas fundamentais da engenharia urbana: contra o Recife da linha reta, da simetria, da regularidade, reafirmava o desleixo dos becos coloniais, ruas estreitas de doces sombras, a irregularidade expressiva de seus conjuntos urbanos: ${ }^{60}$ "isto não impede de gozar a beleza solene das avenidas e das longas retas; a questão, é que elas não abusem do seu imperialismo". ${ }^{61} \mathrm{O}$ próprio Centro Regionalista do Nordeste proporia encampar as discussões em um tal "Mês da Cidade", para o qual Gilberto anteciparia um rol de proposições sobre planejamento nos trópicos:

O Recife é das cidades do Brasil das que possuem maior riqueza de paisagem e de tradição local a defender, a fixar, a desenvolver num tipo original de cidade. E estamos precisamente no momento de planejar-lhe a expansão dentro das suas condições de cor tropical, dentro da sua paisagem toda de doces claridades, de água metendo-se familiarmente entre as casas, entre as ruas, em canais e rios; [...] ruas camaradas da gente. A necessidade delas é das primeiras urgências a conciliar com a necessidade que entre nós se aguça dos largos espaços para o tráfego pesado. ${ }^{62}$

Tratava-se de incorporar ao espírito de renovação o zelo pelas tradições arquitetônicas, pelos elementos de descontração, aconchego e adaptação tropical de ruas e praças; ora enfatizando o patrimônio, ora os usos cotidianos em detrimento do absolutismo da higiene e da circulação.

\section{Oriente etnográfico e a cidade moderna}

Nesse conjunto de representações que emerge da atividade do cronista há, por certo, um elemento de convicção que perpassa o engajamento no Centro Regionalista e no Livro do Nordeste, publicação comemorativa do centenário do Diário de Pernambuco em 1925, no Congresso de 1926 ou no Mês da Cidade, e que antecipa muitas das idéias, imagens e formulações de seu Guia prático, histórico e sentimental da cidade do Recife, publicado em 1934. De fato a sua atuação jornalística conduz o elenco de aspectos que irão constar de seus roteiros. Isto é patente, por exemplo, na coincidência com o temário cultural do jornal A Província a partir de 1928: matérias encomendadas a Ma- 
nuel Bandeira sobre arte, literatura, cinema, arquitetura moderna e relíquias coloniais; a Agache, Estelita e Nestor de Figueiredo sobre urbanismo; a Mario Sette, Ribeiro Couto, Eduardo de Moraes e Salomão Filgueira sobre os mocambos; a Antônio Freire, Aníbal Fernandes, Estevão Pinto sobre patrimônio; a Ascenso, Ernani Braga, Luis Jardim sobre artes plásticas, música e literatura. Pouco a pouco, Gilberto Freyre ia elaborando uma nova cartografia histórica e cultural da cidade.

A experiência pessoal de viajante ${ }^{63}$ não deve ter sido desprezada pelo cicerone maduro. Em seu diário de juventude, ${ }^{64}$ principalmente ao longo dos cinco anos de ausência do país, Gilberto registrou sua aproximação ao estrangeiro para além do cotidiano universitário e das leituras. No Texas de 1918 a 1920, o contato com a cidade fora motivo de indignação - pela degradação da vida nos guetos negros de Waco - e interesse antropológico - pelos espanholismos e mexicanismos indígenas em San Antonio, por exemplo. O fato é que nos breves registros de incursão ao mundo extra-acadêmico norte-americano, raça e cultura surgiam recorrentes. Na "viagem macabra" a Dallas, a brutalidade assassina dos racistas provoca consternação; em Nova York, desde 1920, o clima cosmopolita o contagia - "quase a impressão de ser um tanto nova-iorquino". E de tal modo que já em janeiro de 1921 escreveu a Oliveira Lima:

New York está cheia de museus, bibliotecas, jardins, monumentos, casas velhas, de eras desfeitas, cantos cheios de cor e interesse, onde a gente imagina estar em terras distantes - como o bairro árabe, com seus bazares e suas cores estridentes, o chinês com suas lanternas e os seus amarelos, o judaico e outros ("Carta a Oliveira Lima, 17 jan. 1921”, em Freyre, 1978, p. 172).

Curiosas impressões da metrópole norteamericana, moderna e pluricultural, que entrecruzam bairros orientais com os roaring twenties desta Nova York plena de filistinismo e free love em tavernas, estúdios e cabarés. Oscilação entre a paixão antropológica pelo outro e o eterno retorno à terra natal que o conduz à referência familiar: "Há Greenwich Village, no outro lado de
Washington Square, em cujos sobrados de águas furtadas, o holandês antigo dono de New York, parece ter deixado um pouco de si próprio, como no velho Recife. Vagando por lá imagina a gente que está no velho Recife" (Idem, ibidem). Não mais no Deep South que lhe evocara o Nordeste açucareiro, mas em plena Nova York: nem mesmo quando revisitada de passagem em 1926, sem a nostalgia do exílio, iria perder um halo de "cidade das mil-e-uma-noites". ${ }^{65}$

Foi na longa viagem pela Europa entre 1922 e 1923 que se aguçou o estranhamento: "para um brasileiro verdadeiramente outro mundo". O tom geral já era talvez de maior disponibilidade: a maravilhosa Paris com sua Sainte-Chapelle, o museu Rodin e os cafés da rive gauche amada; as características Berlim e Munique, expressionistas até na arte de seus reclames e tabuletas comerciais; a Londres com seu paisagismo pitoresco. Mesmo em Oxford, onde demorou e se encontrou consigo mesmo, "meu ambiente como em nenhum lugar já meu conhecido", entre chás aristocráticos e parties a vinho do Porto, a atmosfera universitária atenuava-lhe a matriz americana em sua formação. Em toda parte, o charme deste mundo tão profundamente aristocrático e tradicional quanto superburguês e metropolitano o enfeitiça. Mesmo ali onde a passagem para o ambiente nacional se prefigura na Paris de Vicente do Rego Monteiro, Brecheret, Tarsila e Oswald; ou na Lisboa, onde circula a literatura brasileira, às vésperas do retorno ao Brasil - a expansão cosmopolita predomina (Freyre, 1975, pp. 22-125). Talvez porque a dimensão de formação intelectual e moral do grand tour tenha se imposto sobre a experiência do turismo. Talvez porque os próprios momentos de lazer, aventura e descontração tenham sido eternamente mediados pela sociabilidade universitária de Baylor, Columbia, Oxford ou Sorbonne. Se em suas andanças pela Europa o viajante redescobre a diferença étnica e nacional como valor, o turismo ressurge em sua dimensão de urbanidade, como aptidão cortês para viver no outro, como prática de deslocamento cultural e aprendizagem, como entrega dionisíaca ao desconhecido.

Das viagens pelo Brasil naqueles anos, pouco se sabe. Uma das viagens importantes neste 
período foi ao Rio de Janeiro em março de 1926. Primeira viagem ao sul modernista, a motivação inicial foi política. Tratava-se de acompanhar Estácio Coimbra, futuro governador de Pernambuco e seu grande admirador e protetor, em sua despedida do Senado. A estadia no Rio seria relativamente longa, mês no qual conviveria intensamente com a elite política, os jornalistas e os críticos à volta de Assis Chateubriand e principalmente com os modernistas, o mesmo círculo que acolhe Mário de Andrade em suas passagens pela cidade naqueles anos: Manuel Bandeira, em casa de quem eventualmente se hospedaria, Rodrigo Melo Franco, Sérgio Buarque, Carlos Drummond, Prudente de Morais Neto, Vila-Lobos, Luciano Gallet e Jaime Ovale, "minha gente aqui no Rio, repito". No caminho para o Rio, passou pela Bahia e escreveu algo muito próximo das impressões que Mário deixaria no percurso inverso: "Casas e igrejas trepadas umas por cima das outras - dir-se-ia uma multidão a espremer-se diante de um fotógrafo". Cidade tipicamente fotogênica como o Rio, Salvador com seu ar mole e oleoso, era "cidade-mãe, cidade-ama de leite das cidades do Brasil, [...] de sugestões de fecundidade. Cidade gorda, de gordos montes, gordas igrejas, de casas gordas", grávida de outras cidades. Bem diferente de São Paulo, onde também pouco demoraria: "cidade feia mas simpática. Talvez se pudesse dizer com exatidão da capital paulista: feia e forte. Como o Recife, metrópole regional. Sente-se que domina uma região e não apenas um Estado. Breve dominará o Brasil" (Idem, p. 192).

$\mathrm{Na}$ capital federal, confirmou as impressões de "sub-rococó" arquitetônico:

[...] faz pena ver o Rio - cidade de situação ideal - sob essa invasão triunfante de mau gosto [...]. Em vez de se conservar a velha confraternidade da mata com a civilização, raspa-se agora o verde para só destacar-se o horror de novos e incaracterísticos arquitetônicos (Idem, p. 183).

A crítica fazia eco ao desprezo pela arquitetura eclética, napoleônica ou vitoriana, desde a matriz: um "bric-à-brac" arquitetônico, ${ }^{66}$ já antevisto por cartão postal. O contraste entre a arquitetura e a natureza aludia à relação do borrão com o mata-borrão:
[...] no Rio, o favor da natureza chega a ser um escândalo. Alastram-se os borrões da arquitetura horrivel. Mas vem a forte beleza da paisagem e os faz empalidecer, sugando-os, chupando-os, atenuando-os, disfarçando-os com a indulgência maternal de um mata-borrão. ${ }^{67}$

Os claros azuis e verdes virgens, as praias voluptuosas e corpos morenos dos banhistas suavizavam os efeitos da concentração urbana e dos horrores arquitetônicos. Ante a publicidade horrível da Avenida Central, as ruas estreitas tão valiosas em uma cidade tropical ${ }^{68}$ ante a estética cinzenta, ${ }^{69}$ de fraque e asfalto dos engenheiros, os restos coloridos e festivos de antes de Pereira Passos, pendurados por cima do Rio novo, o Morro da Favela. ${ }^{70}$

Se a base de sua formação de cicerone vem provavelmente dessa sua experiência de viajante, o retorno ao Recife também se constitui em cuidadosa elaboração de um roteiro pela cidade. Muito da plataforma regionalista será devido a esses circuitos individuais pelo Recife e arredores nos anos de 1920. Seja como flâneur, seja como etnógrafo ou anfitrião, Gilberto Freyre ia testando acessos às dimensões profundas e adormecidas da cidade. O leitmotiv de uma história da criança no Brasil ao mesmo tempo lhe animava o estudo, a introspecção e a pesquisa de campo: lia cronistas e viajantes, pesquisava arquivos patriarcais, entrevistava parentes velhos, contemplava a paisagem física e visitava engenhos de açúcar. Os field work de bicicleta sobre "a vida da gente das mucambarias"; as documentações fotográficas sobre tipos mestiços em diferentes bairros, subúrbios e interiores, sobre a vida de pescadores, sobre as reminiscências mouriscas e ruas velhas da cidade; os desenhos encomendados a Manoel Bandeira, de becos, sobrados, janelas, portões, telhados, tipos populares; os almoços em mesas patriarcais, restaurantes populares e banquetes de babalorixá; a participação em sessões de xangô (Freyre, 1975, pp. 126, 143-144, 147, 152, 165, 172, 175, 206, 224-225); tudo despertava a curiosidade do jovem etnógrafo desempregado. E de tal modo que Gilberto Freyre viria a dividir com o irmão e amigos de boêmia uma garçonnière na Camboa do Carmo, "nosso anexo urbano", espé- 
cie de co-residência, de "barraca" no centro velho da própria aldeia.

Ao mesmo tempo, entusiasmado com o exemplo de Columbia, essa dimensão de estudo se anuncia desde 1924 em um projeto de antropologia urbana que esboça no Recife:

[...] um estudo total de uma rua típica do Recife. [...] Um estudo da vida íntima da rua. Um estudo antropológico, psicológico, sociológico do seu conjunto: casa por casa, sala por sala, quarto por quarto, habitante por habitante. Atitudes e relações com outras ruas. Observação, mensuração, interpretação através de uma participação intensa de observador na vida observada (Idem, pp. 160-161).

A partir de 1928, com a reforma do ensino na Escola Normal que introduziu a cadeira de sociologia em Pernambuco - "eu preferiria que fosse de Antropologia Social, [...] antigo aluno de Boas" -, o estudo da cidade ganhará em sistematicidade, base estatística e pesquisa de campo, ampliando-se inclusive as suas fontes metodológicas para autores como Rivers, Thomas, Morgan, Wissler, Tylor, Von Wiese, Simmel, entre outros (Idem, pp. 207, 221, 225). Ao que parece, a motivação na ocasião era, sobretudo, pedagógica, e se aplicaria ao conhecimento de grupos ameríndios do interior, brasileiros negros do Recife apegados à cultura africana, de meninos e suas brincadeiras na cidade, grupos de vizinhança.

Se no início era freqüentemente acompanhado por cicerones em suas aventuras etnográficas a boêmia jovem no caso da cidade, Pedro Paranhos no interior - logo também surgirá o anfitrião. Em 1924, ou 1925, recebe Francis Butler Simkins, colega de Columbia, nascido fidalgo na Carolina do Sul, que se hospeda com a família e é conduzido por Gilberto a engenhos do interior. Em 1926, recebe o alemão Rudiger Bilden e esposa, amigos de Nova York, que se hospedam em sua garçonière, a caminho do sul para uma pesquisa de um ano sobre a escravidão no Brasil. Também circulam com o Coronel Pedro Paranhos por canaviais e casas-grandes. ${ }^{71}$ Sempre em casa, recebe também Manuel Bandeira, que antes o recebera em Santa Teresa: em 1926 e em 1928, na "toca do regionalismo", a casa de seu irmão em Casa Forte - "nos- so cozinheiro - da toca - José Pedro tem caprichado em preparar para Bandeira quitutes dos mais saborosamente regionais". Também acompanharia naqueles anos Mário de Andrade e Ribeiro Couto. Entre outros visitantes protocolares, recepcionou também o urbanista francês Agache, a quem ofereceu jantar em sua casa de solteiros, de novo "preparado por José Pedro com sua melhor arte de mestre-cuca. [...] Os Agache ficaram encantados com nossos jacarandás. Já conheciam os da casa da nossa família, na Rua do Cotovelo" (Idem, p. 220). É natural que a questão da hospedagem o preocupasse. Tanto que em 1929 diz ter guiado Alfred Agache "ao lugar que ele aprovou como ideal para o futuro Grande Hotel do Recife - escolha minha" (Idem, p. 236). Em suma, na oscilação entre a distância cosmopolita e o mergulho no local, entre a antropologia e o regionalismo, a década de 1920 representara para Gilberto o despertar para o interesse turístico do Recife, o que é visível na montagem do Guia.

\section{O cicerone como sedutor: cidade e cultura}

Desde 1925, por ocasião da morte de Fritz Baedeker, Gilberto Freyre notara a insuficiência dos roteiros turísticos disponíveis: com sua morte, dizia ele, desaparecia uma instituição, os Guias Baedeker, "especie de numetutelar dos turistas. Uma como governante allemã em ponto grande dessas crianças ricas, também em ponto grande, que são os viajantes. Principalmente os que viajam 'não para ver mas para ter visto". 72 Bom e fiel amigo para muitos, pai de numerosa literatura de viagem,

[...] vi Baedeker guiando turistas ruidosos atravez de cathedraes; vi Baedeker levando viajantes a hoteis, a museus, á abbadia de Westminster, ás fontes de Versailles. Uma tarde na Sainte Chapelle, surprehendi umas creaturas sul-americanas que somente a tyrannia germanica de Baedeker teria levado a similhante logar.

Mas havia um tipo de viagem para quem o velho Baedeker pouco ajudaria: a viagem que 
acabava de empreender, "de um mundo ao outro. E o "outro" não é nenhum dos da veneranda "Revista dos Dois Mundos".

Se a morte de Baedeker não passara despercebida, as diferenças na concepção da viagem tornar-se-iam evidentes quando Gilberto iniciasse o seu projeto de guias de cidades brasileiras: o primeiro, para Recife; em 1939, um outro para Olinda. Em pós-escrito ao Segundo guia prático, bistórico e sentimental de cidade brasileira, situou a novidade de seu empreendimento, anterior inclusive à "magnífica American Guide Series" (Freyre, 1960). Também trabalho de escritor desempregado, os seus Gilberto aproximava menos dos guias de turismo convencionais, ${ }^{73}$ do que das monografias de regiões e cidades, com a diferença de que o conteúdo histórico e sociológico era literariamente trabalhado e acrescido de informação prática.

A redação deve ter sido rápida, pois em dezembro de 1933, o mesmo ano em que disse tê-lo redigido, havia publicado Casa-grande E senzala. De fato, as últimas páginas do Guia revelam precipitação. Se o ritmo geral é o da sedução, acolhendo e conduzindo o leitor vagarosamente pela cidade, há uma visível aceleração da narrativa no final, que arremata o assunto impaciente, insolitamente, como se soubesse a impossibilidade de esgotá-lo, inevitavelmente deixando algo de lado. As dicas finais de locomoção - obrigatórias em todo guia anônimo - têm a graça de um assunto que se esvai em reticências. Decididamente é um guia de autor, menos prático que histórico e sentimental, que se dirige a um viajante culto e se exprime em um estilo inconfundivel para propor ao forasteiro uma determinada leitura do território descortinado. Publicado no Recife em 1934, o guia é ilustrado por um rico conjunto de imagens ${ }^{74}$ e colorido à mão por Luís Jardim. Na capa já se anuncia uma chave interpretativa: a aquarela retrata um pátio de igreja recifense, com seus sobrados multicoloridos, a linha do horizonte marcada por uma silhueta de telhados e torres e o mar ao fundo; na folha de rosto, a gravura situa o bairro de São José, o cenário assobradado completando-se no punhado de mocambos e casas térreas em primeiro plano, típicas do bairro operário. Revisado por alguns dos jovens discípulos, o autor informa as suas fon- tes: jornais pernambucanos, a revista do Instituto Arqueológico, crônicas históricas, livros de viajantes e diários de família.

O destinatário é pronunciado: o viajante, o visitante, o turista ocupam cada página. Também a atitude do cicerone se entrevê na maneira como a ele se dirige: "o visitante não deixe de ir", "o turista prove", "lembre-se o turista que". Abre-se a ele já na ocasião do desembarque:

[...] o viajante que chega ao Recife por mar, ou de trem, não é recebido por uma cidade escancarada á sua admiração, á espera dos primeiros olhos gulosos de pittoresco ou de cor. Nenhum porto de mar do Brasil se offerece menos ao turista. Quem vem do Rio ou da Bahia, cidades francas, scenographicas, photogenicas, um ar sempre de dia de festa, as igrejas mais gordas que as nossas, casas trepadas umas por cima das outras como grupo de gente se espremendo pra sair num retrato de revista, uma hospitalidade facil, derrama$\mathrm{da}$ - talvez fique a principio desapontado com o Recife. Com o recato quase mourisco do Recife, cidade acanhada, escondendo-se para traz dos coqueiros, e angulosa, as igrejas magras, os sobrados estreitos. Cidade sem saliencias nem relevos que deem na vista, toda ella num plano só (Freyre, 1934).75

Apresentada à distância, o cicerone enuncia um "caráter": mourisca e recatada, plana e arborizada, com suas igrejas e sobrados magros, a sua força de sedução é remetida ao mistério. Mas se a chegada por mar ou terra não tem nada de empolgante, a perspectiva aérea de avião ou Zeppelin é mais alegre, colorida pelas grandes manchas verdes e azuis de água. Cruzamento cubista de ângulos que logo mostrará a relatividade das impressões. Fenomenicamente, no Recife, o "melhor encanto consiste mesmo em deixar-se conquistar aos poucos. É uma cidade que prefere namorados sentimentaes a admiradores immediatos". Como nas aproximações galantes, também do turista exige-se vagar, medida, lento desvelar.

Em sua primeira edição, o Guia é um ensaio contínuo, de prosa ritmada, o vagar descontraído e sinuoso por seus objetos sugere um percurso variado pela cidade: da presença histórica francesa, o autor nos conduz aos marcos da civilização 
européia fixados no século XIX; do refinamento francês, leva-nos ao fausto das festas urbanas, como as da Semana Santa, suas procissões, andores e confrarias, muitas das quais - avança o narrador - responsáveis por hospitais e instituições de assistência, algumas das quais podem ser úteis ao viajante conhecer; das obras de igrejas e dos sineiros negros de Domingo, o itinerário se alonga pelo circuito de arquitetura religiosa. É nos meandros da narrativa histórica que a cidade aparece ao viajante, sensual, plástica, imprevistamente. Em linhas gerais, poderíamos dividi-lo em alguns grandes roteiros que se escalonam e se entremeiam na escrita. As primeiras páginas do Guia remetem à crônica da presença estrangeira na cidade: do pirata inglês James Lancaster no século XVI ao fitopatologista alemão Konrad Guenther no século XX - para quem experimentar o cair da noite tropical "foi como se tivesse reconquistado uma amante" - o cicerone cortês evoca a contribuição e as impressões históricas dos visitantes. Recomenda o destino turístico pelo testemunho autorizado dos antecessores e ao mesmo tempo acentua a heterogeneidade e o hibridismo étnico, religioso, social e cultural da cidade. Tratava-se de facilitar ao visitante a apropriação da cidade, coisa que Freyre viajante conhecia muito bem: "Cheguei a amar Munich por me lembrar dos nossos arcos diante dos seus arcos" (Idem). Do passado, o dado trivial, próprio aos deleites sem compromisso: um "Recife romântico" apresentado ao turista sem a solenidade do compêndio e da erudição, de que "todo viajante que se presa foge prudentemente, com as valises tomadas pelos objetos de uso, pelos frascos de saes, pelos romances leves". Tece-se, assim, uma genealogia do turista contemporâneo: herdeiros de ingleses, "históricos viajantes"; de holandeses; de norte-americanos sempre em missões; de franceses, pirateando e civilizando; de chineses, italianos, alemães. De todos eles, retendo contribuições, ainda que perdendo muito "do seu mistério mourisco" à medida que urbanizava e europeizava, como notaria o autor em Sobrados e mucambos (Freyre, 1936) dois anos depois.

Um segundo roteiro leva à arte barroca e à arquitetura colonial, verdadeiras balizas aos itine- rários pelo centro histórico da cidade: da igreja do Rosário à de São Pedro, daí à igreja do Livramento e à do Terço; do convento de São Francisco ao da Penha, ao do Carmo e à igreja Madre Deus; da igreja da Conceição, a de Santo Antônio etc.: se "não há no Recife nenhuma maravilha de arte religiosa", se "o barroquismo romântico exprimiu-se aqui nuns avontades deliciosos", num "encontro íntimo de espontaneidade", "fácil de sentir mas difícil de interpretar", compreende-se que a visita às igrejas seja entremeada de passeios por seus bairros tradicionais, populares como São José ou aristocráticos como Casa Forte, espécie de evasão rumo a seus entornos cotidianos e sentimentais. Da história da arte à história da cidade, as igrejas do Rosário e de São José do Ribamar, por exemplo, conduzem o visitante ao folclore. Talvez um terceiro itinerário, pelo qual Freyre leva o turista ao africano brasileiro: a música, as festas e os maracatus levam o turista aos subúrbios pobres e xangôs, "uns, em mocambos a sombra de grandes gamelleiras ou entre coqueirais. Outras em casinhas de barro sumidas na mocambaria do Fundão"; aos lugares mal-assombrados, ao jogo do bicho, à medicina caseira. É precisamente pelo interesse cultural que se valoriza no Guia também a vida dos trabalhadores braçais: carregadores de piano, de sacos e fardos com seus cantos de trabalho; pescadores e suas lendas de mar, sua adoração às águas e aos astros, suas jangadas - "de uma simplicidade tal que só sendo de povo primitivo - dos povos que os anthropologistas chamam primitivos". Cultura como fator de mobilidade e hibridismo, não por acaso é neste ponto do livro que surgem as praias, revelando a riqueza da mestiçagem; que surge o carnaval, com seus traços africanos misturados às brincadeiras européias.

Presença européia que abre o livro, cenário colonial que perdura na arquitetura católica e suburbana; cultura popular como sincretismo visível na religiosidade, na cor da pele, nas festas tradicionais, o roteiro introduz um dos elementos dominantes na caracterização lírica e geográfica da cidade: oriental, recatada, mas também feminina e aquática:

[...] raras cidades como o Recife com tanta água. Dois rios, um deles vindo dos sertões aqui se en- 
contram, dividem a cidade em ilhas; e a maré vem quase dentro das casas, aos quintais. [...] Irmã água. Não água parada mas água viva. Já Joaquim Nabuco notava que as águas do Recife não eram como as de Veneza, doentias, porém claras e saudáveis. E o recifense foi sempre um camarada d’água (Freyre, 1934).

Até melhor do que Veneza: além de aquática, ao menos depois da obra de Saturnino de Brito, "o serviço d’água no Recife é ótimo". Só lhe faltava reapropriar-se sabiamente de suas margens, de seus leitos, de suas perspectivas. ${ }^{76}$

Havia também um roteiro gastronômico: ditado pelos peixes e frutos do mar, pelos doces, sorvetes, cremes e sobremesas; os melhores restaurantes e os restaurantesinhos "com seu bocado de cor local". Valia à pena visitar também os mercados e orientar-se pelo calendário das frutas da época, que o guia gentilmente oferecia ao visitante. Pelo paladar, Gilberto propunha reconduzir o turista às partes velhas da cidade, cheias de negras de fogareiro, vendedores de amendoim, de bolo, de caldo de cana, vendedores ambulantes de fruta, de galinha, de macaxeira, de peixe, de ostra, e não apenas de vassouras e espanadores. Às vezes homens e mulheres do interior, com seus adereços e utensílios bastante rústicos. De novo, era um caráter mestiço da cidade que o cicerone percorria, pois

[...] as ruas do Recife variam muito de fisionomia, de cor, de cheiro. Parecem às vezes de cidades diferentes. Há ruas perfeitamente européias como a Avenida Rio Branco. Outras que dão a idéia de se estar no Oriente como a Estreita do Rosário á noite, como o beco do Cirigado, o Beco do Marroquim, a Rua do Fogo; ainda outras que não têm que ver as de Lisboa, com seus sobrados, suas varandas, suas vidraças, seus verdes, seus encarnados, seus azuis. Tal a Larga do Rosário. E há as ruas silenciosas (do poema de Cardozo). Enquanto certos trechos da cidade dão a lembrar cidades do Senegal. Trechos com mucambos, casas de palha - que, aliás, não são tão ruins, sob o ponto de vista da higiene, como os cortiços e as ilhas feias, tristonhas, em que se ensardinha a pobreza européia (Freyre, 1934).

Nas relações e confrontos com outras civilizações, o autor redescobria a cidade como um arqui- pélago de culturas, o caráter de suas ruas e bairros confirmando também o elogio do mocambo.

O final do percurso conduzia à informação inevitável: serviços de assistência, instalações urbanas, museus, edifícios públicos, serviços de transporte e comunicações, os horários de embarque, as companhias em operação, dados de população e de clima. No meio, o ensaísta insistiria em um velho tema, as árvores: "na República não se sabe por que estranho sentido de arte ou de higiene tropical, os prefeitos do Recife deram para perseguir as árvores como quem persegue inimigos". Como se para autenticar a assinatura regionalista: "só nos últimos anos tem se feito reação [...], pressão de campanhas jornalísticas e do Centro Regionalista do Nordeste". Imodestamente anunciava a filiação do novo itinerário à plataforma crítica: a cidade desnudada pelo cicerone reforçava os valores há anos defendidos. Valor não puramente sentimental: se "ao estrangeiro inteligente não atraem as avenidas novas nem as praças novas" (Freyre, 1975, p. 75), o passado e a cultura logo se imporiam como capital simbólico.

\section{A cidade do outro e a cidade profunda}

Ao final, o vasto itinerário parece breve, tal a contenção e a economia com que o cicerone opera os seus quadros de valor. Apesar do foco na cidade, reúne ao crivo regionalista os princípios básicos do hibridismo e do tropicalismo firmados em Casa-grande \& senzala: a reabilitação do oriental (Araujo, 1994, p. 47; Said, 1990, pp. 174-205) opera na ordem da pluralidade genealógica a que se filia o caráter desta cidade em seu processo de civilização. De fato se, em Casagrande, Freyre havia proposto reinterpretar o passado ibérico, mouro e moçarabe herdado de Portugal ao lado das contribuições indígenas e africanas, no Guia, os valores pitorescos do mistério, do recato e da simplicidade, a tonalidade castanha da gente, sua sensualidade e misticismo, remetidos à sua formação mista de distintas procedências, credos, raças e culturas (Freyre, 1933, pp. 242ss.), devem surgir na paisagem e na cultu- 
ra como algo pulsante, visível, atraente. Do passado ao presente, ao menos aqui, em 1934, não a "decadência" como claramente surgirá em Sobrados e mucambos, mas talvez a "transição" para a modernidade revela permanências do patriarcalismo (Freyre, 1922, pp. 113-114) e recombina de maneira nova aspectos meio-medievais, meio-árabes, meio-levantinos, meio-andaluzes (Freyre, 1925) com os traços afro-brasileiros e populares na cidade moderna. ${ }^{77}$ Pode-se objetar que o Guia não tem o alcance de um ensaio de história social e cultural da cidade. Em todo caso, destinado a atrair o interesse do viajante ao revelar a mesma simpatia regionalista pelo passado e pelo exótico, não resta dúvida de que o Guia prático, histórico e sentimental insiste no valor da mistura e da diferença, dando-lhes prioridade em relação às representações da ruína e da miséria que logo se imporão em Sobrados e mucambos.

Seja como for, há um nítido parentesco com as críticas à modernidade de artifício elaboradas por Mário. Ambos defendem as tradições vivas do povo, os aspectos de diferenciação e estabilização cultural nas suas manifestações; em ambos, a mesma ironia em face da rejeição dos valores da selva e do clima, que se exprimem objetivamente na crítica ao tratamento geométrico das árvores na cidade; nos dois, o mesmo desprezo às demolições de igrejas e ruas velhas em nome do tráfego, às reformas ineptas e restaurações descaracterizadoras. O próprio sarcasmo com que se referem ao ecletismo também os aproxima na complacência diante da retomada estilística da arquitetura colonial, ainda que menos programática no Mário de fins da década (Andrade, 1928). O fato é que, assim como Gilberto, o escritor paulista estava atento ao caráter e à perda de caráter das cidades brasileiras. Havia por certo cidades incaracterísticas como Manaus, Belo Horizonte, e até o Rio de Janeiro e o Recife, que denunciavam o irreconciliável entre a natureza e a civilização, o novo e o arcaico, a modernidade e a miséria; cidades ainda moças, inteiramente abertas ao futuro como $\mathrm{Na}$ tal, como São Paulo (Lopez, 2004), mas havia também aquelas onde era possível surpreender e se comover com uma personalidade característica. Belém era uma delas:
O Brasil possui algumas cidades bonitas: O Rio, Belo Horizonte, Recife, São Paulo: mas, a todas falta caráter. Belém é como Ouro Preto, como Joinville, como São Salvador; possui beleza característica. Este céu de mangueiras, filtrando sol sobre a gente, produz uma ambiência absolutamente original e lindíssima. ${ }^{78}$

Belém, Ouro Preto, Salvador, Joinville, núcleos fortes de colonização luso-brasileira, afrobrasileira e teuto-brasileira, respectivamente. Também nisso, qual Gilberto, uma dimensão cultural da cidade ganhava força: ao turista aprendiz não devia passar despercebida a sua etnicidade.

Os motivos são efetivamente os mesmos: o caráter das cidades, a arte e a arquitetura coloniais, o clima e a praia, a comida e as frutas, a música e as festas populares, suas crenças e valores culturais. Mas o que os diferencia afinal na experiência da viagem, nos papéis que assumem ao longo dela, nas estratégias de localização do outro e no seu rebatimento sobre o viajante? O interesse de Mário pelo mundo popular, apesar de sua pouca familiaridade com a antropologia, era naqueles anos de 1920 mais consistente e decidido do que no Gilberto recém-chegado de Columbia, chocado com as transformações de sua cidade e inegavelmente comprometido com uma herança patriarcal. Não há de ser irrelevante o contraste entre a indignação e a revolta que ressoam no diário do turista, e o absoluto silêncio no guia do cicerone ante as condições de vida do povo pobre do Nordeste. Se o Mário da Lopes Chaves é filho dos salões aristocráticos da cidade mais industrializada do país, o que apanhou da vida do seringueiro e do cantador nas expedições ao Norte e ao Nordeste não ganhará o selo de curiosidade folclórica; a sua etnografia encaminhando-se para a arte de vanguarda e a crítica social. Já o Gilberto da Camboa do Carmo é ainda um típico flâneur dos trópicos, as suas experiências etnográficas na cidade limitando-se ao experimento pedagógico, expressão idiossincrática ou auto-expressiva, misticismo metodológico voltado para outros tempos e outros mundos; as suas melhores realizações de fato concentrando-se na maneira criativa como reúne história íntima, psicologia social e antropologia da cultura na interpretação da 
vida urbana das camadas privilegiadas da sociedade imperial (Freyre, 1922, 1925, 1936). Não por acaso, entre as últimas estampas encomendadas para seu Guia, na seqüência de uma imagem de mocambos, acrescentou narcisicamente " $u m$ casarão patriarchal (Estrada de Dois Irmãos)". Era a mesma casa de Apipucos na qual, recém-casado, o cicerone definitivamente viria a se estabelecer.

Não é irrelevante que na experiência de viagem Mário se apresente como aprendiz e Gilberto como cicerone. O turista que não segue qualquer guia, mas apalpa o território, de um lado; de outro, o guia que escapa aos roteiros previsíveis para desviar o viajante das impressões de superfície, da cenografia urbana, da aparência imediata. Se os itinerários trilhados pelo primeiro são de evasão, de distanciamento espacial, de deslocamento no outro mundo e, ao mesmo tempo, de passagem de uma configuração a outra do sentido, ou seja, de temporalização do sentido, os roteiros sugeridos pelo segundo acompanham um movimento de enraizamento, de deslocamento no interior de seu próprio mundo. Se, no primeiro caso, temos um mergulho decidido nas divisões internas do eu-viajante, um extravio voluntário; no segundo, trata-se de redespertar a cidade profunda, diversa, colorida, no lirismo do escritor.

Mas se o Gilberto Freyre bem instalado naufraga em seu próprio universo perdido, o jangadeiro Mário de Andrade não escapa à sedução, na rapsódia convertendo-se no amoroso cantador da terra vista. Amor cortês e resistência à norma civilizada reaproxima cicerone e viajante na procura de uma contribuição singular do país junto ao passado, ao mito, à brincadeira infantil, à vida popular. Mais difícil é perceber o que os separa nesta empreitada, o que separa os seus escritos na literatura de viagem (Guagnini, 2000, pp. 13-27). Afinal, auto-consciente do poder de seus itinerários, o regionalista não evita as dimensões sombrias da cidade que percorre; do mesmo modo, fugindo à identidade e aos valores de partida, o modernista descreve um norte muito próximo aos desvios propostos pelo outro. Não seria de indagar, ao fim e ao cabo, se o turista ideal do guia prático não é o próprio turista aprendiz? Se não é este que o primeiro tem em mente? Se ao final de sua jornada não é aquele que o turista reencontra no extravio ou na procura deliberada do que se sonega em todo guia de turismo? Ou se, antes ao contrário, o turista aprendiz não estará inviabilizando em sua jornada a própria hipótese de um guia, com seus roteiros prévios? Em favor de uma concepção do livro de viagem como texto que se move na experiência imediata, única, singular, intransferível do deslocamento? Que transforma o viajante, que nele desnuda o que há de estranho na sua própria identidade de origem? Que é inseparável de seus interesses subjetivos, sentimentais, de seus humores, de seus guias afetivos amigos, discípulos, informantes, homens e mulheres comuns - passo a passo desviando-se do percurso previsível? Que não sonega as indicações do sonho, do cansaço, do sono, da embriaguês, da fantasia, da audição, do olfato?

Se os dois escritos revelam um outro rumo nas cidades brasileiras, ao menos esta grande diferença nos permite compará-los: se O turista aprendiz descobre a personalidade anônima como traço ao mesmo tempo distintivo e humano nos itinerários que vai trilhando, é porque o seu destino é a transformação de si mesmo; se o Guia sentimental revê a sua origem como ponto privilegiado de visão do mundo, é porque se funda nas confirmações da própria identidade quando dela se afasta. Mário volta profundamente transformado da viagem; Gilberto cada vez mais bem instalado no seu porto seguro.

\section{Notas}

1 "Informações: o urbanista Agache e o plano de remodelação do Recife", Boletim de Engenharia, ano V, III (1): 21-23, Recife, out. 1927.

2 Em sua primeira conferência no Rio de Janeiro, em junho de 1927, Agache definiria o urbanismo também como uma disciplina da polidez. O urbanista era a um só tempo artista, cientista e filósofo social, dotado de experiência visual e prática acumulada nas obras e gosto apurado em viagens pelo mundo.

3 G. Freyre, "Mestre Agache no Recife; trecho de uma reportagem para jornal, ampliada em conferência, 
1927”, em Freyre (1964, p. 116). Freyre provavelmente se refere à reportagem "Um urbanista, o Rio e o Recife", Jornal do Comércio, Recife, 15/7/1927, p. 3.

4 G. Freyre, "Artigos numerados: 99", Diário de Pernambuco, 8/3/1925 (apud Freyre, 1979, pp. 128130). Praticamente todos os artigos de Gilberto Freyre publicados no Diário de Pernambuco aqui citados foram extraídos desta compilação.

5 G. Freyre, "Mestre Agache no Recife", op. cit., p. 119.

6 Idem, pp. 117-118.

7 G. Freyre, "Morreu Fritz Baedeker", em Freyre (1935, p. 133).

8 Em 24 de julho de 1928, Manuel escreveu para Mário, "Gilberto me convidou para escrever duas vezes por semana sobre atualidades cariocas". Em 29 de setembro de 1928, Manuel afirma produzir para o jornal quatro artigos mensais (cf. Marcos A. de Moraes, 2000, pp. 397-398, 407).

9 Cf. "Carta de Bandeira à Mário, Rio de Janeiro, 9/11/1928”, em M. A. de Moraes (2000, p. 409).

10 M. de Andrade, "Notas de viagem (11/12/1928)", em Andrade (1983, p. 347).

11 M. de Andrade, "Ano bom de 1926", em Mello (1991, p. 72).

12 Testemunho de estranhamento entre os dois antes do Congresso de Regionalismo é o artigo de J. Inojosa, "Tradição e tradicionalistas" (1925).

13 Em 1905 conheceu o mar de Santos, em que sua mãe se tratara; em 1913, foi a Araraquara, em luto pela morte do irmão; em 1918, a Poços de Caldas, acabado o luto do pai, com a mãe e os irmãos; em 1919, depois de se ordenar, pela primeira vez a Minas Gerais, "passando pelas cidades históricas, descobre o barroco e o Aleijadinho"; ao Rio de Janeiro, foi antes de 1920, ver arte religiosa, em 1921 foi se encontrar com Manuel Bandeira e em 1923, com o carnavalesco carioca (cf. Lopez, 1993, p. 109, 111; Lopez, 1993; "Carta a Manuel Bandeira, São Paulo, fevereiro 1923”, em Moraes, 2000, p. 84; Andrade, 1920, pp. 292-293).

14 Em 1924 e 1926, quando Mário compôs o "Noturno de Belo Horizonte" e a maioria dos poemas de
Clã do Jaboti, "já se pode ver que domina uma razoável informação sobre tradições brasileiras”. Exatamente em 1925, Mário se interessava por folclore, "lia e procurava autores que lhe dessem base para estudos de Folclore. Assim sendo, pode-se supor que Sílvio Romero, Pereira da Costa, Mello Moraes Filho e Couto de Magalhães estavam sendo freqüentados por Mário de Andrade depois de 1922" (cf. Lopez, 1972, pp. 77-78).

15 "Carta a Manuel Bandeira, São Paulo, 6/4/1927", em M. A. de Moraes (2000, pp. 340-341).

16 Em seu ensaio de interpretação de Macunaima, Gilda de Mello e Souza reencontrou via Bakhtin a matriz satírica, popular e carnavalizada na montagem da rapsódia brasileira. "Mário de Andrade - à semelhança dos cantadores nordestinos, que estudara com tão aguda compreensão - "desmanchava” a linha melódica européia, para que, rejuvenescida pelas acomodações locais, fecundada pelo riso popular, ela ascendesse novamente ao nível da grande arte" (G. de M. e Souza, 1980, pp. 12, 14, 22-23, 26, 32, 79-80, 83-84, 103).

17 "Pretendo escrever um livrinho sobre a viagem" ("Carta a Cascudo, São Paulo, 30/4/1927”). Cf. Veríssimo de Mello, 1991, p. 78; Andrade, 1983, edição de Lopez, pp. 35-36.

18 "Uma palestra com um espírito culto", Folba do Norte, Belém, maio 1927, em Andrade (1983, p. 332).

19 Idem, p. 333.

20 "Carta de Mário a Sérgio Olindense, São Paulo, 2/11/1929”, em Branco (1971, pp. 92-93).

21 Desde cedo denunciada pela topografia médica, a mudança da paisagem urbana incluía o aterro de igarapés e a derrubada de árvores, que os sanitaristas de Manaus julgavam um agravante epidêmico (cf. Costa, 1999, p. 93).

22 Diário Oficial, Manaus, 8/7/1927, apud A. M. de Figueiredo (2001, pp. 273-276).

23 Álbum, 1929. Um exemplar foi pessoalmente doado pelo prefeito a Mário em 1929.

24 Ver interpretação do episódio proposta por G. de. M. e Souza (1979, pp. 93-96). 
25 “Carta a Câmara Cascudo, São Paulo, 1/3/1927", em Mello (1991, p. 75).

26 “Cartas a Câmara Cascudo, São Paulo 26/9/1924" e “Araraquara, 26/6/1925”, em Mello (1991, pp. 34-35).

27 "Carta a Câmara Cascudo, São Paulo 4/10/1925", em Mello (1991, p. 42).

28 "Carta a Cascudo, São Paulo, 3/2/1926", em Mello (1991, p. 53).

29 "Carta a Cascudo, São Paulo, 22/1/1928", em Mello (1991, p. 85).

30 Os cantos e o $\operatorname{coco}(15 / 12 / 1928,29 / 1 / 1929)$, a chegança e marujada (18/12/1928), o cantador (20/12/1928), os ritos de feitiçaria e o catimbó (22/12, 26/12, 27/12, 28/12/, 3/1/1928), as músicas e as danças na praia (30/12/1928), as orações e os cantos religiosos (31/12/1928), a alegria do povo (1/1/1929), as festas de Reis (6/2/1929), o coqueiro Chico Antônio (10, 11 e 12/1/1929), o cangaço (23/1/1929), os santos afro-brasileiros (25/1/1929), os Congos (26/1/1929), o Boi Tungão e o ganzá (27/1/1929), os Caboclinhos (5/2/1929), que arrematam o seu roteiro para o leitor do jornal.

31 L. da C. Cascudo, "O novo plano da cidade - I - a Cidade", A República, 247, Natal, 30/10/1929; "O novo plano da cidade - II - a Ribeira no 'Master Plan'”, A República, 252, Natal, 7/11/1929 (apud Dantas, 2003, pp. 159-162). Em outra ocasião, tratei com Dantas dos contrastes e dos encontros de Mário com as cidades de Natal e Recife (cf. Dantas e Lira, 2001, pp. 636-650).

32 Carmem Portinho, "Os progressos constantes da aviação”, A República, 85, Natal, 16/4/1929 (apud Dantas, 2003).

33 Cf. "Intellectuaes illustres", A União, 24, Paraíba, 29/1/1929.

34 "Carta de Manuel Bandeira a Mário de Andrade, 22 de agosto de 1927", em M. A. de Moraes (2000, p. 348).

35 Cf. G. Freyre, "Artigos numerados: 52", Diário de Pernambuco, Recife, 13/4/1924.

36 Idem, 20/4/1924.
37 G. Freyre, "Acerca do Recife", Diário de Pernambuco, Recife, 7/6/1925.

38 G. Freyre, "Da tirania da Pedra Azul, livra-nos, ó senhor", Diário de Pernambuco, Recife, 19/3/1926.

39 A coleção fotográfica de Mário de Andrade encontra-se no Instituto de Estudos Brasileiros da USP.

40 G. Freyre: "Artigos numerados: 53", Diário de Pernambuco, 20/4/1924; "Do bom e do mau regionalismo", Revista do Norte 5, Recife, out. 1925; "Ruas de doces sombras", Diário de Pernambuco, 5/9/1926; "Acerca do Recife", Diário de Pernambuco, 7/6/1925. A proposta de reaproximação da Veneza com as águas não seria de todo ignorada nos anos subsequentes, o plano do arquiteto Nestor de Figueiredo, de 1931, debatido longamente no interior da Comissão do Plano da Cidade, entre idas e vindas reduzido ao limites da reforma do bairro de Santo Antônio reservava para as margens fluviais um tratamento viário e paisagístico especial (cf. Figueiredo, 1933; Lira, 1997, pp. 261-262, 272-285).

41 S. Filgueira, "Os mocambos serão menos pitorescos que os chalets de Boa Viagem?", A Provincia, Recife, 15/3/1929; R. R. Couto, "Cartas da França", A Província, Recife, 8/5/1929; E. de Moraes, "Como acabar com o mocambo no Recife", A Província, Recife, 16/5/1929; M. Sette, "Mocambos da pobreza do Recife", A Provincia, Recife, 2/2/1930 (cf. Lira, 1997, 1998).

42 Ernani Braga, "Vida musical: Mário de Andrade", $A$ Provincia, Recife, 21/2/1929 (transcrito em O turista aprendiz, p. 378).

43 Ver os trabalhos de figuras como Henrique Castriciano, Manoel Dantas, Augusto Tavares de Lyra, Rocha Pombo e Eloy de Souza, este último autor de um artigo sobre os cantadores populares para o Livro do nordeste, organizado por Gilberto Freyre em 1925, recentemente revisados por Dantas (2003, cap. 2).

44 Joaquim Ignacio, Notícia de uma viagem à Paraíba, em 1924, Mossoró, 1987 (apud Almeida, 2003).

45 Teses incluídas no "Programa-convite" do Congresso conforme Azevedo (1983, pp. 180-181).

46 Entre os quais intelectuais e artistas como José Américo de Almeida, Gilberto Freyre, Ascenso Fer- 
reira, Joaquim Cardozo, Otávio Brandão, Mário Sette, Joaquim Inojosa, Alfredo Fernandes, Samuel Campelo, José Maria de Albuquerque e Mello; arquitetos e engenheiros como Nestor de Figueiredo, Salomão Filgueira, Francisco Boulitreau, Antônio Jannuzzi; empresários como Carlos Lira Filho, Júlio Bello, Odilon Nestor; políticos, sanitaristas oficiais e altos funcionários como Luíz Cedro, Samuel Hardman, Amaury de Medeiros, Alfredo de Moraes Coutinho, Octávio de Freitas, Gouveia de Barros.

47 G. Freyre, "A propósito de Guilherme de Almeida", Diário de Pernambuco, 15/11/1925.

48 "Carta a Luís da Câmara Cascudo, 6/9/1925”, em Veríssimo de Mello (1991, pp. 39-40).

49 Muitos dos artigos publicados por Freyre naqueles anos foram reunidos em Tempo de Aprendiz (1979). Sobre as relações entre modernismo e ciências sociais no autor, ver Araújo (1994). A este respeito, ver a conferência realizada pelo sociólogo em São Paulo, após sua eleição para o Congresso em 1946 (Freyre, 1946).

50 G. Freyre, "Artigos numerados: 53", Diário de Pernambuco, Recife, 20/4/1924.

51 G. Freyre, "Artigos numerados: 64", Diário de Pernambuco, Recife, 29/6/1924. Cf. G. Freyre, "Acerca do Recife", Diário de Pernambuco, Recife, $7 / 6 / 1925$.

52 G. Freyre, "Artigos numerados: 53", Diário de Pernambuco, Recife, 20/4/1924.

53 G. Freyre, "Artigos Numerados: 60", Diário de Pernambuco, Recife, 8/6/1924. Cf. também o "Artigos numerados: 83", Diário de Pernambuco, Recife, $15 / 11 / 1924$.

54 G. Freyre, "A vitória dos coretos", Diário de Pernambuco, Recife, 19/7/1925.

55 G. Freyre, "Reação do bom gosto", Diário de Pernambuco, Recife, 24/11/1925.

56 G. Freyre, "Artigos numerados: 68", Diário de Pernambuco, Recife, 3/8/1924.

57 G. Freyre, "Artigos numerados: 72", Diário de Pernambuco, Recife, 31/8/1924.

58 G. Freyre, "Acerca de jardins", Diário de Pernambuco, Recife, 3/5/1925.
59 G. Freyre, "O Recife e as árvores", Diário de Pernambuco, Recife, 12/11/1924.

60 G. Freyre: "Da tirania da pedra azul, livra-nos ó Senhor!", Diário de Pernambuco, Recife, 25/2/1926; "Ruas de doces sombras", Diário de Pernambuco, Recife, 5/9/1926.

61 G. Freyre, "A propósito de urbanismo", Diário de Pernanbuco, Recife, 14/11/1926.

62 G. Freyre, "O mês da cidade", Diário de Pernambuco, Recife, 31/10/1926.

63 No sentido oposto ao itinerário antropológico por excelência, rumo a alguns dos centros universitários mais importantes na década de 1920 (cf. J. Clifford, 2000, pp. 51-79).

64 Seu diário de juventude, organizado por anos em 1975, cobre o período de ausência do país entre 1918 e 1923, incluindo muitas de suas experiências de viagem.

65 G. Freyre, "New York", Diário de Pernambuco, Recife, 29/4/1926.

66 G. Freyre, "Artigo numerado: 64", Diário de Pernambuco, Recife, 6/7/1924. A alternativa de estilo regional, brasileira e americana, surgindo-lhe na figura do colonial, das missões e do georgiano, combinado ao material arqueológico indígena ou popular. Cf. "A vitória dos coretos", Diário de Pernambuco, Recife, 19/7/1925; "Reação do bom gosto”, Diário de Pernambuco, Recife, 24/11/1925.

67 G. Freyre, "Sugestões do Rio", Diário de Pernambuco, Recife, 25/3/1926.

68 G. Freyre: "Ruas de doces sombras", Diário de Pernambuco, Recife, 5/9/1926; "A cidade da febre cinzenta”, Diário de Pernambuco, Recife, 17/10/1926.

69 Como notou Ricardo Benzaquen de Araújo, o tema do desbotamento do mundo na paleta de Freyre aparece no enfoque da decadência da bybris colonial sob o imperialismo civilizador (cf. Araujo, 1994, pp. 134-136ss.).

70 G. Freyre, "Sugestões da favela", Diário de Pernambuco, Recife, 3/10/1926.

71 G. Freyre, "Impressões de Pernambuco", Diário de Pernambuco, Recife, 20/1/1926. 
72 G. Freyre, "Morreu Fritz Baedeker", Diário de Pernambuco, Recife, 26/4/1925.

73 Sobre a especificidade do gênero, ver Adamo (2000, pp. 105-118).

74 Algumas delas, históricas: paisagens e panoramas; outras foram especialmente encomendadas pelo autor a Luís Jardim num total de 28 imagens. Além delas, 16 fotografias detalham as cenas desenhadas, além de retratos de família. O Guia é complementado por dois mapas: um, de toda a planície recifense, com a indicação das linhas de transporte; o outro ampliado ao Bairro do Recife e à parte de Santo Antônio, situando o porto, a estação de hidroaviões, os ancoradouros, cais, as docas e todo um conjunto de monumentos e pontos de interesse para o visitante.

75 A primeira edição do Guia prático, histórico e sentimental da cidade do Recife não apresenta numeração de páginas; tanto quanto possível as citações que se seguem estão sincronizadas com a temporalidade interna do texto.

76 Gilberto Freyre fazia eco à discussão contemporânea da reapropriação urbanística das margens de rio. Já em 1930, o arquiteto Nestor de Figueiredo viria a incorporar a referência fluvial no desenho da cidade. No anteprojeto que encaminhou à municipalidade alguns anos depois, defendeu o tratamento das margens do rio em um sistema de parques urbanos: nos trechos centrais, como áreas de apoio a eventos náuticos, esportivos, de exposições e feiras; na altura dos arrabaldes, como bosque com funções recreativas (cf. Figueiredo, 1933).

77 Claramente posto na ordem do dia de suas preocupações em 1933 e no mesmo ano de 1934, suscitando a organização no Recife do I Congresso Afro-Brasileiro, para o qual Mário de Andrade enviaria uma comunicação acerca das imbricações e das confusões entre a mentalidade cultivada e a mentalidade popular na definição das calungas de Maracatu que estudara no Recife em sua viagem de 1929 (cf. Freyre, 1935).

78 "Uma palestra com um espírito culto", Folha do Norte, Belém, maio 1927 (transcrito em M. de Andrade, 1983, p. 333).

\section{BIBLIOGRAFIA}

ADAMO, S. (2000), "Os guias de viagem", in L. de S. Caprara (org.), Brasil e Itália; viajando entre duas culturas. São Paulo, Lemos Editorial.

AGACHE, D. A. (1930), "O que é o urbanismo", in PDF, Cidade do Rio de Janeiro: extensão, remodelação e embelezamento, 1926-1930, Paris, Foyer Brésilien.

ALMEIDA, M. C. F. de. (2003), Viajante, cronista e aprendiz de Turista: olhares sobre a cidade da Parabyba na década de 1920. São Carlos, (mimeo.).

ANDRADE, M. (1920a), "A arte religiosa no Brasil: triumpho eucharístico de 1733”. Revista do Brasil, 13 (49): 5-12.

(1920b), "A arte religiosa no Rio". Revista do Brasil, 13 (52): 289-293.

(1920c), "A arte religiosa no Brasil: em Minas Gerais". Revista do Brasil, 14 (54): 102-111.

. (1928), "Arquitetura colonial”. Diário Nacional, 23-26 ago., São Paulo.

. (1929), "O que o sr. Mario de Andrade viu pelo Nordeste". A Província, 16 fev., Recife.

. (1976), Poesias completas: Clã do Jaboti. São Paulo, Círculo do Livro.

. (1983), O turista aprendiz. 2 ed. São Paulo, Duas Cidades (edição de T. A. P. Lopez).

ARAUJO, R. B. de. (1994), Guerra e paz: Casagrande E senzala e a obra de Gilberto Freyre nos anos 30. Rio de Janeiro, Editora 34.

AZEVEDO, N. P. de. (1984), Modernismo e regionalismo, os anos 20 em Pernambuco. João Pessoa, Secretaria de Educação e Cultura.

BANDEIRA, M. (1928a), "Urbanistas cuidado! O Recife é uma cidade magra". A Província, 30 dez., Recife. 
. (1928b), "Salvemos a Madre de Deus". A Provincia, 1 dez., Recife.

BARROS, S. (1975), Um movimento de renovação cultural. Rio de Janeiro, Cátedra.

BENJAMIN, W. (1987), Obras escolbidas II. São Paulo, Brasiliense.

BRANCO, C. H. C. (1971), Macunaima e a viagem grandota. São Paulo, Quatro Artes.

BRITO, F. S. (1942), Saneamento de Recife. Rio de Janeiro, Imprensa Nacional, 2 vols.

BRUANT, Catherine. (1996), "Donat Alfred Agache: urbanismo, uma sociologia aplicada", in Luiz Cesar de Queiroz Ribeiro e Robert Pechman, Cidade, povo e nação: gênese do urbanismo moderno, Rio de Janeiro, Civilização Brasileira, pp. 167-201.

CARDOSO, S. (1988), "O olhar do viajante (do etnólogo)", in A. Novaes (org.), O olhar, São Paulo, Companhia das Letras.

CARDOZO, J. (1985), "Prefácio-testemunho dos aspectos sócio-culturais", in S. Barros, $A$ década 20 em Pernambuco, Recife, Fundação de Cultura da Cidade.

CASCUDO, L. C. (1928), "Cidade do Natal do Rio Grande". Revista de Antropofagia, 4.

CHACON, V. (1993), "Gilberto Freyre, Mário e Oswald de Andrade”. Ciência e Trópico, 21 (1): 7-16 (número especial em homenagem a Mário de Andrade).

CIACCHI, A. (1995), "Introduzione", in M. de Andrade, Il turista apprendista, Roma, Biblioteca del Vascello.

CLIFFORD, J. (2000), "Culturas viajantes", in A. A. Arantes (org.), O espaço da diferença, Campinas, Papirus.

COsTA, A. (1928), "O Recife de hoje". A Provincia, 2 nov., Recife.

COSTA, F. D. S. da. (1999), "Quando viver ameaça a ordem urbana: Manaus 1900-1915", in D. R. Fenelon, Cidades, São Paulo, PUC-SP/Olho d'Água.

DANTAS, G. A. F. (2003), Linhas convulsas e tortuosas retificações: transformações ur- banas em Natal nos anos 1920. São Carlos, EESC-USP.

DANTAS, G. \& LIRA, J. (2001), "Contrastes e encontros: história, cultura e cidade no Nordeste (Natal e Recife, 1928-1929)". Anais do IX Encontro Nacional da Anpur, Rio de Janeiro, Anpur, vol. 2.

DIAS, A. (1904), O Brazil actual: informações geographicas, politicas e commerciaes; impressões de viagem, dados pittorescos e descriptivos sobre as principaes cidades brazileiras [...]. Rio de Janeiro, Imprensa Nacional.

DUARTE, P. (1971), Mário de Andrade por ele mesmo. São Paulo, Edart.

ESTELITA, J. (1929), "Pernambuco deve organizar a defesa dos seus monumentos". A Provincia, 6 jan., Recife.

FERNANDES, F. (1946), "Mário de Andrade e o folclore brasileiro". Revista do Arquivo Muncipal, CVI: 135-158.

FIGUEIREDO, A. M. de. (2001), "Edinea Mascarenhas Dias: a ilusão do Fausto: Manaus, 1890-1920". Revista Brasileira de História, 21 (40): 273-276.

FIGUEIREDO, N. de. (1933), "O Recife de amanhã”. A Província, 11 maio, Recife.

FREYRE, G. (1922 [1964]), Vida social no Brasil nos meados do Século XIX. Recife, Instituto Joaquim Nabuco.

. (1925), "Vida social no Nordeste: aspectos de um século de transição", in Arquivo Público Estadual, Livro do Nordeste, comemorativo do $1^{\circ}$ Centenário do Diário de Pernambuco, 1825-1925, Recife, Arquivo Público Estadual (ed. fac-similar, 1979).

. (1933), Casa-grande E senzala. Rio de Janeiro, Maia \& Schmidt.

(1934), Guia prático, bistórico e sentimental da cidade do Recife. Recife, The Propagandist. 
(org.). (1935), Estudos afro-brasileiros. Rio de Janeiro, Ariel.

. (1935), Artigos de Jornal. Recife, Mozart.

(1936), Sobrados e mucambos: decadência do patriarcado rural no Brasil. São Paulo, Companhia Editora Nacional.

(1946), Modernidade e modernismo na arte política. São Paulo, Cruzeiro do Sul.

. (1960), Olinda: segundo guia prático, bistórico e sentimental de cidade brasileira. 3 ed. Rio de Janeiro, José Olympio.

. (1964), Retalhos de Jornais Velhos. 2 ed. Rio de Janeiro, José Olympio.

(1975), Tempo morto e outros tempos: trechos de um diário de adolescência e primeira mocidade, 1915-1930. Rio de Janeiro, José Olympio.

(1978), Cartas do próprio punbo sobre pessoas e coisas do Brasil e do estrangeiro. Rio de Janeiro, MEC/Imprensa Nacional.

. (1979), Tempo de aprendiz: artigos publicados em jornais na adolescência e na primeira mocidade do autor (1918-1926). São Paulo, Ibrasa/MEC.

GUAGNINI, E. (2000), "Estudar a literatura de viagem (e os guias) hoje", in L. S. Caprara (org.), Brasil e Itália: viajando entre duas cultura, São Paulo, Lemos Editorial.

INOJOSA, J. (1925), "Tradição e tradicionalistas". Revista de Pernambuco, II (11).

(1969), O movimento modernista em Pernambuco. Rio de Janeiro, Tupy, vol. 3.

LAFETÁ, J. L. (2000), 1930: a crítica e o modernismo. 2 ed. São Paulo, Duas Cidades.

LEITE, I. B. (1996), Antropologia da viagem. Belo Horizonte, Editora da UFMG.

LÉVI-STRAUSS, C. (1987), "As descontinuidades culturais e o desenvolvimento econômico", in , Antropologia estrutural dois, Rio de Janeiro, Tempo Brasileiro.

LIRA, J. T. C. de. (1995), "Técnica sanitária e o traçado da cidade". Pós 5: 69-84.
(1997), Mocambo e cidade: regionalismo na arquitetura e ordenação do espaço habitado. São Paulo, FAU-USP.

(1998), "Mots cachés: lieux du Mocambo à Recife”. Genèses, 33: 77-106.

LOPEZ, T. A. P. (1972), Mario de Andrade: ramais e caminho. São Paulo, Duas Cidades.

(1983), "Viagens etnográficas de Mário de Andrade", in M. de Andrade, O turista aprendiz, São Paulo, Duas Cidades.

(1993), "As viagens e o fotógrafo", in Mário de Andrade: fotógrafo

e turista aprendiz, São Paulo, IEB-USP.

(1993), Eu sou trezentos, sou trezentos-e-cincoenta: uma "autobiografia" de Mário de Andrade. São Paulo, Secretaria Municipal de Cultura/IEB-USP.

(org.). (2004), De São Paulo: cinco crônicas de Mário de Andrade, 1920-1921. São Paulo, Sesc-SP/Senac.

LUBAMBO, K. (1991), Bairro do Recife: entre o Corpo Santo e o Marco Zero: a reforma urbana no início do século XX. Recife, Fundação de Cultura Cidade do Recife.

MASCARENHAS, E. D. (1999), A ilusão do Fausto: Manaus, 1890-1920. Manaus, Valer.

MELLO, Veríssimo de (org.). (1991), Cartas de Mário de Andrade a Luis da Camara Cascudo. Belo Horizonte, Vila Rica.

MEYER, M. (1993), "Um eterno retorno: as descobertas do Brasil", in __ Caminhos do imaginário do Brasil, São Paulo, Edusp.

MORAES, E. J. de. (1999), Limites do moderno: o pensamento estético de Mário de Andrade. Rio de Janeiro, Relume Dumará.

MORAES, M. A. de (org.). (2000), Correspondência Mário de Andrade \& Manuel Bandeira. São Paulo, Edusp/IEB.

MOREIRA, F. D. (1994), A construção de uma cidade moderna: Recife, 1909-1926. Recife, MDU-UFPE. 
NERY, M. F. -J. de Santa-Anna. (s.d), Aux ÉtatsUnis du Brésil: voyager de M. T. Durand. Paris, Delagrave.

ORLANDO, A. (1908), Porto e cidade do Recife. Recife, Typ. do Jornal do Recife.

OUTES, J. (1991), Recife pregado à cruz das grandes avenidas, 1927-1945. Recife, MDU.

PEIXOTO, F. (1992), "O nativo e o narrativo: os trópicos de Lévi-Strauss e a África de Michel Leiris". Novos Estudos CEBRAP, 33: 173-186.

PERES, F. da R. (org.). (1987), Protesto contra a demolição da Sé, 1928. Salvador, UFBA (Centro de Estudos Bahianos, Publicações, 127).

PINHEIRO, E. P. (2002), Europa, França e Babia: difusão e adaptação de modelos urbanos (Paris, Rio e Salvador). Salvador, EDUFBA.

PONTUAL, V. (2001), Uma cidade e dois prefeitos. Recife, Editora da UFPE.

PREFEITURA de Manaus. (1929), Album Municipal de Manaós, elaborado na administração do prefeito Araujo Lima. Amazonas, Prefeitura de Manaus.

RAFFAINI, Patricia Tavares. (2001), Esculpindo a cultura na forma Brasil: o Departamento de Cultura de São Paulo (19351938). São Paulo, Humanitas.

REZENDE, A. P. (1997), (Des)encantos modernos: bistórias da cidade do Recife na década de vinte. Recife, Fundarpe.

RICOEUR, Paul. (1955), "Civilisation universelle et cultures nationales", in Histoire et verité, Paris, Seuil, pp. 274-288.

SAID, E. (1990), Orientalismo. São Paulo, Companhia das Letras.

SALGUEIRO, V. (2002), "Grand Tour: uma contribuição à história do viajar por prazer e por amor à cultura". Revista Brasileira de História, 22 (44): 289-310.

SANDRONI, C. (1988), Mário contra Macunaíma. São Paulo, Vértice.
SARGES, M. de N. (1990), Riquezas produzinho a belle époque: Belém do Pará (1870/1910). Recife, UFPE.

. (1999), "Belém: um outro olhar sobre a "Paris dos trópicos" (1897-1911)", in M. A. Soller e M. I. S. Mattos (orgs.), $A$ cidade em debate, São Paulo, Olho d’Água.

SILVA, G. G. da. (1987), "Arquitetura eclética em Pernambuco", in A. Fabris (org.), Ecletismo na arquitetura brasileira. São Paulo, Nobel.

SOUZA, E. M. de. (1999), "Autoficções de Mário", in $\longrightarrow$ A pedra mágica do discurso, Belo Horizonte, Editora da UFMG.

SOUZA, E. M. de \& SCHMIDT, Paulo (orgs.). (1997), Mário de Andrade, carta aos mineiros. Belo Horizonte, Editora da UFMG.

SOUZA, G. de M. e. (1978), "O avô presidente". Discurso, 9: 97-105.

. (1979), O tupi e o alaúde. São Paulo, Duas Cidades.

. (1980), Exercícios de leitura. São Paulo, Duas Cidades.

. (2000), "O mestre de Apipucos e o turista aprendiz". Teresa, 1: 72-90.

TRAJANO FILHO, F. S. (2003), D.V.O.P.: arquitetura moderna, Estado e modernização, Paraíba, década de 1930. São Carlos, EESC-USP.

VIANNA, A. J. B. (1900), O Recife, capital do estado de Pernambuco. Recife, s/ed.

WRIGHT, M. R. (1901), The new Brazil: its resources and attractions; historical, descriptive and industrial. Philadelphia, George Barrie \& Son. 


\section{NAUFRÁGIO E GALANTEIO: VIAGEM, CULTURA E CIDA- DES EM MÁRIO DE ANDRADE E GILBERTO FREYRE}

\author{
José Tavares Correia de Lira
}

\section{Palavras-chave}

Mário de Andrade; Gilberto

Freyre; Viagem; Cidades; Mo-

dernismo brasileiro.

$\mathrm{Na}$ literatura de viagem, dois gêneros tradicionais se destacam: o diário e o guia; e dois personagens: o viajante e o cicerone. O objetivo deste artigo é avançar na compreensão das cidades como campo cultural na perspectiva da viagem e dos viajantes. Para tal, proponho repensar a distância entre Mário de Andrade e Gilberto Freyre, figuras centrais do modernismo e da antropologia no Brasil, a partir do exame de suas experiências de viagem. Mais especificamente, trata-se de encenar um encontro entre estas personalidades diversas, às vezes antagônicas, em um topos comum de acesso à cultura brasileira: as cidades do Norte e do Nordeste do Brasil, surpreendidas na crise do regime agro-exportador e patriarcal, com seus resíduos de paisagem e caráter, povo e modos de vida, memória, forma urbana, arquitetura, arte e folclore. A base de leitura são os diários e crônicas redigidos pelo escritor paulistano ao longo de suas duas longas viagens etnográficas à Amazônia (1927) e ao Nordeste (1928/1929); o diário de juventude, as crônicas de jornal e o Guia Prático, Histórico e Sentimental da Cidade do Recife (1934), do antropólogo pernambucano. Se a opção por estes escritos - menores no conjunto de suas obras, é verdade, porém sólidas posições nos gêneros em que se incluem - instiga o turista e o cicerone a uma relação de proximidade, neles é possível flagrar, ao lado da viagem prazerosa, uma dimensão exploratória e etnográfica da sociedade moderna.

\section{SHIPWRECK AND GAL- LANTRY: TRAVEL, CULTURE, AND CITIES IN MÁRIO DE AN- DRADE E GILBERTO FREYRE}

José Tavares Correia de Lira

\section{Keywords}

Mário de Andrade; Gilberto

Freyre; Travel; Cities; Brazilian

modernism.

In the literature of travel, two traditional orders come up, the journal and the guide, as well as two characters, the traveler and the cicerone. The objective of this article is to advance in the comprehension of cities as some cultural field on the perspective of both the travel and the travelers. In order to do so, I propose the rethinking of the distance between Mário de Andrade and Gilberto Freyre, central figures of Brazilian modernism and anthropology, by examining their travel experiences. More specifically we show a meeting between these two diverse personalities, sometimes antagonistic, in a common topos to access the Brazilian culture: Northern and Northeastern Brazilian cities caught in the crisis of the agro-exporting and patriarchal regimes with their remains of landscape and character, peoples and ways of life, memories, urban setup, architecture, folklore, art. The reading bases are the journals and chronicles written by the writer from São Paulo state along his two long ethnographical journeys to the Amazonian (1927) and to the Northeastern (1928/1929) regions as well as youth journals, newspaper chronicles, and the Guia Prático, Histórico e Sentimental da Cidade do Recife (1934) - "Practical, Historical, and Sentimental Guide of the City of Recife (1934)," by the anthropologist from Pernambuco state. If the option for such writings - less important in their authorship but constituting solid positions in the genre - instigates the tourist and the cicerone towards a relation of proximity, it is possible to take a snapshot of, together with the pleasurable travel, an exploratory and ethnographic dimension of the modern society.

\section{NAUFRAGE ET GALANTERIE: VOYAGE, CULTURE ET VILLES DANS L'GEUVRE DE MÁRIO DE ANDRADE ET DE GILBER- TO FREYRE}

\author{
José Tavares Correia de Lira
}

\author{
Mots-clés \\ Mário de Andrade; Gilberto \\ Freyre; Voyage; Villes; Moder- \\ nisme brésilien.
}

Dans la littérature à propos des voyages, deux genres traditionnels apparaissent : le journal de bord et le guide ; et deux personnages : le voyageur et le cicérone. L'objectif de cet article et d'avancer dans la compréhension des villes en tant que champ culturel dans la perspective du voyage et des voyageurs. Dans cet article, nous proposons de repenser la distance entre Mário de Andrade et Gilberto Freyre, figures centrales du modernisme et de l'anthropologie au Brésil, à partir de l'examen de leurs expériences de voyage. Plus spécifiquement, il s'agit de mettre en scène une rencontre entre ces deux personnalités distinctes, parfois antagonistes, en un topos commun d'accès à la culture brésilienne: les villes du Nord et du Nordeste du Brésil, surprises par la crise du régime agro-exportateur et patriarcal, avec leurs résidus de paysage et de caractère, de peuple et de modes de vie, de mémoire, de forme urbaine, d'architecture, d'art et de folklore. La base de lecture sont les journaux de bord et les chroniques rédigées par l'écrivain paulista tout au long de ses deux longs voyages ethnographiques en Amazonie (1927) et au Nordeste (1928/1929); le journal de jeunesse, les chroniques de journal et le Guide Pratique, Historique et Sentimental de la Ville de Recife (1934), de l'anthropologue originaire du Pernanbouc. Si l'option pour ces écrits - d'importance mineure dans l'ensemble de leurs œuvres, mais qui constituent, néanmoins de solides positions par rapport aux genres dans lesquels ils s'incluent - instiguent le touriste et le cicérone à une relation de proximité, il est possible de constater, à côté d'un voyage plaisant, une dimension exploratrice et ethnographique de la société moderne. 